Insight, part of a Special Feature on Advancing Social-Ecological Research Through Teaching: Social-Ecological Systems Framework and Design Principles in Large Areas

\title{
Linking classroom learning and research to advance ideas about social- ecological resilience
}

\author{
Natalie C. Ban ${ }^{1}$, Emily Boyd ${ }^{2,3}$, Michael Cox ${ }^{4}$, Chanda L. Meek ${ }^{5}$, Michael Schoon ${ }^{6}$ and Sergio Villamayor-Tomas $^{7}$
}

\begin{abstract}
There is an increasing demand in higher education institutions for training in complex environmental problems. Such training requires a careful mix of conventional methods and innovative solutions, a task not always easy to accomplish. In this paper we review literature on this theme, highlight relevant advances in the pedagogical literature, and report on some examples resulting from our recent efforts to teach complex environmental issues. The examples range from full credit courses in sustainable development and research methods to project-based and in-class activity units. A consensus from the literature is that lectures are not sufficient to fully engage students in these issues. A conclusion from the review of examples is that problem-based and project-based, e.g., through case studies, experiential learning opportunities, or real-world applications, learning offers much promise. This could greatly be facilitated by online hubs through which teachers, students, and other members of the practitioner and academic community share experiences in teaching and research, the way that we have done here.
\end{abstract}

Key Words: complex systems; interdisciplinarity; pedagogy; problem-based learning; project-based learning; social-ecological resilience; social-ecological systems; teaching

\section{INTRODUCTION}

Human society is faced with complex environmental problems that require innovative solutions (Berkes et al. 2003, Folke et al. 2005), and hence there is an increasing demand in higher education institutions for this type of training. Emerging interdisciplinary endeavors of social-ecological systems (Ostrom 2009), resilience (Maynard et al. 2010, Neubauer et al. 2013), sustainability science (Clark and Dickson 2003, Chapin et al. 2010), complex systems (Gunderson and Holling 2002), among others, which together we refer to as social-ecological resilience, are well-poised to contribute to finding solutions to contemporary sustainability conundrums, and have the potential to serve as a platform for teaching complex, interdisciplinary issues. However, teaching such multidimensional, emerging themes effectively can be challenging not only because of the complexity of the issues, but also because they ideally integrate multiple disciplinary and interdisciplinary perspectives and learning techniques (Laurillard 2002) at a time when the dominant educational model reinforces single discipline-oriented learning.

We review literature on teaching these themes, highlight relevant advances in the pedagogical literature, and report on some of our efforts toward innovative attempts to teach complex environmental issues. We ask, how can students be taught about complex environmental issues and solutions in a way that reflects current pedagogical research? The purpose of this paper is to briefly summarize the relevant literature and to share our efforts of improving undergraduate and graduate teaching and learning about coupled social and environmental issues with clear relevance to society. We summarize our courses that have attempted such integration, and provide a self-assessment of the benefits, challenges, and opportunities for improvement. Our intent is not to examine the efficacy of different teaching techniques, as has been done elsewhere, but rather to review approaches and our own experiences for teaching social- ecological resilience. Our goal is to provide ideas and motivation for others to learn from, and improve upon, our efforts.

\section{METHODS}

Social-ecological resilience and education literature

Environmental governance and resilience issues are an emerging research theme, and hence we wanted to identify the status of advice about teaching such themes to university students. We searched the Web of Knowledge for literature on social-ecological systems, or sustainability science, or complex systems, and environment $(n=439)$. We subset this search with educational key words, e.g., education, or classroom, or teaching, or pedagogy, or learning, and the research area of educational research $(n=82$ articles). We then reviewed the abstracts to identify those specifically investigating educational approaches to teaching these subjects to university students ( $\mathrm{n}=13$, see Appendix 1$)$.

To identify broader trends and recommendations in pedagogy, beyond the theme on social-ecological resilience as per the search outlined above, we started with recent high profile papers, e.g., in Science, Proceedings of the National Academy of Sciences, (Handelsman et al. 2004, Ruiz-Primo et al. 2011, Freeman et al. 2014), and used a snowball approach to identify other relevant scholarship. We focused on studies that quantitatively assessed learning approaches. Our purpose with these reviews was to highlight some approaches that hold promise for engaging students with ideas around environmental issues, socialecological systems, resilience, etc.

We also summarize our own experiences relating to the challenges, opportunities, and examples of teaching these themes. We are mostly early-career scholars with a common interest in resilience and social-ecological system, who discussed this paper at a meeting of the Resilience Alliance (France, 2014). The courses we reflect on have been taught at five universities in Europe and

\footnotetext{
${ }^{1}$ School of Environmental Studies, University of Victoria, ${ }^{2}$ School of Archaeology, Geography and Environmental Sciences, University of Reading, ${ }^{3}$ Stockholm Resilience Centre, Stockholm University., ${ }^{4}$ Environmental Studies Program, Dartmouth College, ${ }^{5}$ Department of Political Science, University of Alaska Fairbanks, ${ }^{6}$ School of Sustainability, Arizona State University, ${ }^{7}$ Division of Resource Economics, Humboldt University
} 
Table 1. Courses used as case studies in this article.

\begin{tabular}{|c|c|c|c|c|c|}
\hline Course name & University \& department & Description & Focus & Teaching methods & Deliverables \\
\hline $\begin{array}{l}\text { Analyzing environmental } \\
\text { issues using a social- } \\
\text { ecological systems } \\
\text { perspective (case study } 1 \text {, } \\
\text { Appendix 2) }\end{array}$ & $\begin{array}{l}\text { University of Victoria } \\
\text { (Canada), School of } \\
\text { Environmental Studies }\end{array}$ & $\begin{array}{l}\text { Combined upper- } \\
\text { level undergraduate } \\
\text { and graduate course }\end{array}$ & $\begin{array}{l}\text { Methods, } \\
\text { research }\end{array}$ & $\begin{array}{l}\text { Active learning, } \\
\text { problem-based } \\
\text { learning, case } \\
\text { studies }\end{array}$ & $\begin{array}{l}\text { Assignments leading to a } \\
\text { term paper, some submitted } \\
\text { as peer-reviewed } \\
\text { contributions }\end{array}$ \\
\hline $\begin{array}{l}\text { Social-ecological research } \\
\text { methods (case study } 2 \text {, } \\
\text { Appendix 3) }\end{array}$ & $\begin{array}{l}\text { Dartmouth College } \\
\text { (USA), Environmental } \\
\text { Studies }\end{array}$ & $\begin{array}{l}\text { Upper-level } \\
\text { undergraduate } \\
\text { course }\end{array}$ & $\begin{array}{l}\text { Methods, } \\
\text { research }\end{array}$ & $\begin{array}{l}\text { Active learning, } \\
\text { project-based } \\
\text { learning }\end{array}$ & $\begin{array}{l}\text { Research proposals designed } \\
\text { to guide senior theses or } \\
\text { graduate work }\end{array}$ \\
\hline $\begin{array}{l}\text { Policy and Governance in } \\
\text { Sustainable Systems (case } \\
\text { study 3, Appendix 4) }\end{array}$ & $\begin{array}{l}\text { Arizona State University } \\
\text { (USA), School of } \\
\text { Sustainability }\end{array}$ & $\begin{array}{l}\text { Upper-level } \\
\text { undergraduate } \\
\text { course }\end{array}$ & $\begin{array}{l}\text { Governance } \\
\text { and } \\
\text { institutional } \\
\text { analysis }\end{array}$ & $\begin{array}{l}\text { Problem- and } \\
\text { project-based } \\
\text { learning, }\end{array}$ & $\begin{array}{l}\text { Consulting reports and } \\
\text { presentations for local } \\
\text { NGOs and municipalities }\end{array}$ \\
\hline $\begin{array}{l}\text { Mobilizing qualitative } \\
\text { evidence to test SES-related } \\
\text { theory (case study } 4, \\
\text { Appendix 5) }\end{array}$ & $\begin{array}{l}\text { University of Murcia } \\
\text { (Spain); Humboldt } \\
\text { University (Germany), } \\
\text { Division of Resource } \\
\text { Economics }\end{array}$ & $\begin{array}{l}\text { Graduate training } \\
\text { workshop }\end{array}$ & $\begin{array}{l}\text { Methods, } \\
\text { research }\end{array}$ & $\begin{array}{l}\text { Problem-based } \\
\text { learning, } \\
\text { experiential } \\
\text { learning, } \\
\text { collaborative } \\
\text { learning }\end{array}$ & $\begin{array}{l}\text { One-page memo } \\
\text { summarizing in-class } \\
\text { analysis, potentially } \\
\text { shareable with authors of } \\
\text { case study reviewed }\end{array}$ \\
\hline $\begin{array}{l}\text { Resilience for Sustainable } \\
\text { Development (case study 5, } \\
\text { Appendix 6) }\end{array}$ & $\begin{array}{l}\text { University of Reading } \\
\text { (UK), Geography and } \\
\text { Environmental Sciences } \\
\text { (GES) }\end{array}$ & $\begin{array}{l}\text { Combined third } \\
\text { year undergraduate } \\
\text { and graduate course }\end{array}$ & $\begin{array}{l}\text { Society, } \\
\text { culture, and } \\
\text { resilience }\end{array}$ & $\begin{array}{l}\text { Research led, } \\
\text { problem-based } \\
\text { learning workshops, } \\
\text { case studies, } \\
\text { blogging and } \\
\text { participation in } \\
\text { serious gaming }\end{array}$ & $\begin{array}{l}\text { Assignments and workshops } \\
\text { leading to term essay, group } \\
\text { work case studies }\end{array}$ \\
\hline
\end{tabular}

North America. Our assessment of the courses involved selfreflection (including discussions with each other), and, where available, formal course evaluations and informal student feedback. Our directly relevant collective experience includes a combined upper-level undergraduate and graduate course in social-ecological systems thinking, an upper-level undergraduate course in social-ecological research methodology, graduate courses on social-ecological-technical systems, undergraduate courses on systems thinking, graduate and undergraduate courses on resilience for sustainable development (Table 1).

\section{RESULTS: CHALLENGES AND OPPORTUNITIES IN TEACHING SOCIAL-ECOLOGICAL RESILIENCE}

Challenges from the literature to teaching social-ecological resilience

Two key challenges to teaching social-ecological resilience and related ideas emerge from the literature (Appendix 1). First, social-ecological systems learning requires engaging students with many relevant disciplinary, multidisciplinary, and interdisciplinary perspectives (Dieleman and Huisingh 2006). Teachers thus need to either relate to students the many different understandings of concepts related to social-ecological resilience, or simplify and focus on only one or a few such perspectives (Sriskandarajah et al. 2010).

Second, and related to the above, social-ecological resilience can be difficult to translate into effective educational strategies because of, as Sriskandarajah et al. (2010:560) state, "profoundly contestable positions on the nature of nature (ontology), the nature of knowing and knowledge (epistemology) and the nature of human nature and the role of values (axiology)." Thus teachers and students need to be able to make the connections between the diverse domains of knowledge, which means bridging different professional cultures, traditions, gender differences, and ages (Dieleman and Huisingh 2006).

\section{Approaches to teaching social-ecological resilience from the literature}

General trends in the evolution of approaches to university teaching over the past $\sim 50$ years can provide some general insights for teaching social-ecological resilience (Slavich and Zimbardo 2012). In particular, there seems to be a shift from conventional lecturing to other learning techniques, e.g., active learning, student-centred learning, experiential learning, transformational teaching, research-led teaching. Although some defend lecturing (Burgan 2006), evidence is mounting that more active forms of instruction enhance student learning through building problemsolving skills rather than perfecting rote memorization (Handelsman et al. 2004). For example, a recent meta-analysis comparing lecturing to active learning in undergraduate science, engineering, and mathematics classes found that examination scores improved by $6 \%$ with active learning and students were less likely to fail (Freeman et al. 2014). Similarly, a meta-analysis assessing course innovations on learning in science found that teaching techniques that incorporated collaborative learning (engaging students with peers as a component of the learning process) led to improved learning over control conditions, as did those involving conceptually oriented tasks, technology innovations, and combinations thereof (Ruiz-Primo et al. 2011). Another study found that small-group learning is effective at promoting greater academic achievement (Springer et al. 1999)

The literature on teaching social-ecological resilience closely reflects the general shift in pedagogical approaches. Teaching and learning are of course closely linked (Biggs and Tang 2011), with 
the aim of teaching to promote learning among students. Ultimately, intertwined teaching and learning about socialecological resilience is aimed at constructing solutions to complex environmental issues. Experiential learning (learning by doing), for example, was integrated into a course in Sweden on integrated water resource management, where soft-systems methodology, which attempts to explore diverse stakeholder perspectives through conceptual models of the selected systems, was used to foster learning and understanding of diverse stakeholders, including through an experiential component where students facilitated real-life multistakeholder processes (Krasny et al. 2009). Transformative social learning, aimed to induce changes in the students' worldview, (Mezirow 1991) was used in a course in the Netherlands where one activity included deconstructing the Happy Meal, and then reconstructing what a happy meal might look like (Sriskandarajah et al. 2010). Activity theory, which suggests that learning occurs through the interaction of the learner with other components of the systems, e.g., other people or tools that help interactions, has also been applied in teaching social-ecological resilience (Krasny and Roth 2010).

Case studies are a common tool for explaining ideas around social-ecological resilience (Dieleman and Huisingh 2006, Fazey 2010). Case studies can engage students with higher level thinking by immersing them in the complexities of social-ecological systems (Fazey 2010). However, case studies have also been criticized because they may limit students to looking for solutions within the boundaries of the case instead of thinking outside the box. To overcome this limitation one study suggests that additional teaching techniques should be combined with case studies to encourage higher level thinking. For example, games can play an important role in getting students to appreciate different points of view (Dieleman and Huisingh 2006).

Computer-supported learning is another technique employed in teaching social-ecological resilience. For example, computersupported collaborative learning is one promising technique (Hmelo-Silver et al. 2011). Similarly, computational representation of complex systems using agent-based models have been used as models for students to experiment with how complex systems work without real-world implications (Jacobson et al. 2011).

\section{Our experience with teaching social-ecological resilience}

Case study 1: analyzing environmental issues using a socialecological systems perspective

A combined upper-level undergraduate and graduate course, this classroom-based learning experience at the University of Victoria, Canada, used case studies to immerse students in socialecological systems ideas (one 3-hr class per week for 13 weeks). The course linked with an ongoing research project by the teacher and others that uses case studies to better understand the governance approaches that work in large social-ecological systems, the Social-Ecological Systems Meta-analysis Database (SESMAD) project (Cox 2014, Epstein et al. 2014a, b, Evans et al. 2014, Fleischman et al. 2014a, b, Villamayor-Tomas et al. 2014). Undergraduate students worked in small groups on case studies of their choosing, and graduate students worked individually. Students were guided through a series of assignments to apply the social-ecological systems framework (Ostrom 2009) to their case studies (Appendix 2), with the ultimate aim of presenting possible solutions to addressing environmental issues in their case studies. Students were thus required to carry out literature-based research because none of their case studies had been analyzed in this way. The novelty of some of the case studies led to contributions to social-ecological resilience research; four of the case studies from the course are currently in review in peerreviewed publications, with more likely to be submitted in the future.

Many aspects of the course worked well, but others proved challenging. The case study approach was a great asset. In the course evaluations many students reflected positively on the case studies, and the series of assignments that walked them through using the social-ecological systems framework. Integrating the course with an active research program of the teacher also motivated students. Indeed, most graduate students and one of the undergraduate groups submitted papers to this Special Feature based on their work during the course. The biggest challenges were the diverse backgrounds of students and engaging everyone in discussions. Some students grasped the complex issues around social-ecological resilience much more quickly than others, and were thus able to participate more effectively in the course. These challenges are not unique to teaching socialecological resilience, but are perhaps exacerbated by the interdisciplinary nature of the topics. Improvements to the course could include more diverse pedagogical techniques to actively engage students in in-class discussions, e.g., games, and interacting with guest speakers to bring alive multiple aspects of social-ecological resilience.

Case study 2: teaching social-ecological methods using standard techniques from social science methods literature

This course at Dartmouth College followed what would be considered a more traditional route to teaching research methods by relying on popular methods textbooks from the social science and common-pool resource research (i.e., Yin 1984, Shadish et al. 2002, Poteete et al. 2010, Bernard 2011). The course was geared toward students interested in conducting research during their senior year of college or potentially afterward in a graduate program. The emphasis was less on theoretical concepts and more on the nuts and bolts of putting together a solid scientific research proposal. Primary topics included research design, sampling techniques, measurement processes, and analytical options, and students were trained to evaluate how well each of these steps were accomplished according to standard criteria, e.g., internal, external, and concept validity, reliability (Appendix 3).

Generally students were able to grasp the basic concepts, although combining them into one coherent research project proved challenging for most. Students generally found the assigned readings to be challenging (read: "boring"), particularly King et al. (1994) and Yin (2014). One challenge was providing the students with sufficient environmental examples because the standard social science textbooks are not usually geared toward environmental issues. Translations needed to be made and, in many cases, issues in the texts were either overemphasized or underemphasized compared to their importance in socialecological research. For example, it is common in social science methods texts to emphasize the importance of experimental and quasi-experimental methods as the primary, if not the only, way of establishing causal relationships among important concepts and variables. "Observational" is taken to be equivalent to 
"descriptive," instead of explanatory. Meanwhile, the majority of empirical work on social-ecological systems (SES) is highly nonexperimental because of the real-world nature of the research questions being addressed.

Similarly, the traditional texts describe threats to internal validity, or the accuracy of causal inferences, that are very specific to projects geared toward the evaluation of specific treatments of cohorts of individuals. For example, "maturation" describes the organic development of human individuals as a possible confounder that may explain over time changes in a longitudinal study, rather than some experimental treatment. This is not very relevant to the great majority of social-ecological studies, while issues such as policy diffusion and spillover effects are highly relevant, but also specific in how they are instantiated in socialecological contexts.

Case study 3: using problem and project-based learning to study social-ecological systems

Problem- and project-based learning (PPBL) allow students to self-guide and direct their learning through engagement beyond the classroom (Brundiers and Wiek 2013; Appendix 4). Rather than having lecture-based classes, PPBL shifts the role of the instructor from "sage on the stage" to "guide from the side." It uses projects to convey two sets of learning, i.e., the core material of the course and skills in project management, problem solving, and team building. There are a number of ways to accomplish this in the classroom ranging from less self-directed learning in more traditional class settings to highly self-directed and realworld oriented. This course used semester-long group projects, which form the core deliverables in a traditional class setting. Students worked in small groups of 5 (12 groups in a class of 60$)$, and selected from a handful of projects across a range of realworld issues in the community. The projects all took a systems approach to coupled social-ecological sustainability and included working with the Arizona State Land Department on conservation on public land, working on community engagement in the clean-up efforts of a Superfund site, and looking at transportation options in a low-income section of Phoenix.

The students split the project up into subprojects and had each team member investigate a portion of the project. They then prepared individual papers on their aspect of the problems being confronted in their project. The next deliverable was a team presentation on the overall problem, integrating the individual components. They also presented potential solutions. After the presentation, they then began researching, as a group, which solution to recommend. Throughout this, the students engaged with the external stakeholder. In doing so, the students built a network of practitioners beyond campus and gained real-world experience that they could discuss with future employers. The combination of individual and group work minimized free riders in the group.

The major challenges were in coordinating stakeholder and student schedules, incorporating the material learned in class into the projects, and finding projects of the appropriate duration and intensity that utilized skills developed in class. The coordination efforts and group facilitation took substantial amounts of time. Also, the class size of 60 students was about the most that could be reasonably accommodated by one professor. Students expressed enthusiasm for engagement beyond academia and enjoyed interacting with practitioners interested in hearing their ideas and solutions. However, like many team-based projects, students complained about unequal capacities from team to team and unequal levels of engagement within teams, a reality of all team-based work.

\section{Case study 4: mobilizing qualitative evidence to test SES-related} theory

This case is based on a one day workshop on community based social-ecological systems research within a training event of The Training Network for Monitoring Mediterranean Marine Protected Areas (MMMPA; Marie Curie European program; Appendix 5). The goal of the workshop was to introduce mostly PhD students with backgrounds in ecology and marine biology to hands-on institutional analysis of local SES. One of the most challenging but also important steps in the research process is using evidence effectively to test and build theory. This challenge is particularly relevant when studying complex SES and manifests differently depending on whether we use quantitative or qualitative data. Two important aspects of the challenge when using qualitative data are the interpretation of the data itself and the test of alternative hypotheses. The activity below aimed to confront students with those challenges.

The workshop was structured into two sessions. The first session introduced SES-theory through conventional lecturing. The lecture focused on common pool resource (CPR) theory and social and ecological variables that are hypothesized to contribute to sustainable resource use using a small set of synthesizing references (Agrawal 2001, Ostrom 2009, Poteete et al. 2010). Causal mechanisms behind the impact of a number of those variables on sustainable outcomes were emphasized, including collective action and game theory. In the second session, students participated in a hands-on in-class activity to familiarize with the theory and experience the methodological challenges of using qualitative data to test it. Students were given a 5-page text that had been adapted from Evans et al. (2014). The paper, which develops a SES analysis of the Great Barrier Reef, was selected to fit the substantive interest of students (marine protected systems and governance) and because it contains thorough and clearly identifiable pieces of qualitative evidence. The text was adapted to include only those pieces and leave out much of the analysis, discussion, and conclusions. The exercise consisted of three sequential steps: students were asked to (1) read the text and use it as their only source of data to identify marine-sector proxies for a number of the CPR theory variables reviewed in the previous session; (2) use the SES framework (Ostrom 2009) to classify the variables into resource system, unit, actor, or governance attributes; (3) pick one relevant variable or group of them and use collective action theory and quotations to justify why that variable could be important. Discussion followed the third step. During the discussion, students were asked to share their classification of variables and interpretation of the data and compare it the work done by their peers. Students' analyses were also compared to the analysis carried in Evans et al. (2014). The discussion was guided to promote collaborative learning through common understanding of similarities and differences across analyses and the reasons behind them. Finally, students were requested to hand-in a one page memo synthesizing their analysis as well as the main points of the discussion. 
Overall, the exercise was intellectually intense and thus challenging for the students. The first step of the exercise resulted in some debate about different ways to interpret data and operationalize SES variables. The second exercise resulted in the identification of a fair number of relevant variables. This was used to confront students with the challenge of balancing parsimony and accuracy when tackling complex SES. Students were asked to mobilize a theory, i.e., a set of theories about the role of CPR variables, that they were not familiar with and assess a 5-page text in a short time frame. Students also found it difficult to constrain themselves just to that set of theories and the evidence provided in the text. Instead, they were incorporating other theories, their own personal knowledge of the case or similar cases and making strong assumptions. If more time were available, extensions of this exercise could include the mobilization of other theories, use of quantitative evidence, e.g., descriptive statistics, nonparametric tests, or regression results, as well as identification of alternative hypotheses by students.

Case study 5: teaching and learning about sustainable development from a social-ecological resilience perspective Resilience for Sustainable Development in the Geography and Environmental Science Department at Reading University, UK is tailored for third year undergraduate human and human/ physical geography students and for Master's level science students attending the Environmental Management MSC programme (Appendix 6). The course aims to teach a systematic evaluation of the principles of resilience both as a theoretical lens and operational concept, one through which to examine how contemporary societies and cultures, predominantly in the developing world, are adapting to global environmental change. The course followed a mixed format with interactive lectures designed around key concepts in social-ecological resilience (e.g., Gunderson and Holling 2002, Berkes et al. 2003, Folke et al. 2005, Ostrom 2009), adaptation, vulnerability, and risk (Adger 2000, 2006, Gallopín 2006), group work around case studies of adaptive governance, and interactive games relating to comanagement. The course comprised 10 lectures and 10 workshops over 11 weeks. The course assignment consisted of an exam, individual essay, and a group case study project. Both undergraduates and graduates tackled an individual essay, which included a literature review of key concepts. In addition, the students were also guided through a group project on the topic of "Imagining society and environmental resilience" presented as a poster, PowerPoint, performance, video clip, or other form of visual representation. Invited speakers gave the students the opportunity to engage with the challenges of implementing resilient sustainable development strategies. The students also played serious games, that is, games that have an explicit educational purpose, and role-plays of multistakeholder environmental initiatives. Games can generate emotional experience and simultaneously stimulate individual thinking and enthuse collective cohesion (de Suarez et al. 2012).

Overall the course worked particularly well for graduate students. Although they came from diverse backgrounds, they generally felt that the mixture of lectures, case studies, interactive games, and discussions were a useful way to learn about and interrogate resilience. At the undergraduate level, feedback varied. Some felt inspired by a "great" class, which was also described as "interesting and topical." Others struggled with the analytical ambiguity of social-ecological resilience and expressed the need for more time to grasp and process concepts. Many of these concerns were directly linked to student aspirations to "do well" in their final marks. This may point to a trade-off between the significant intellectual demands of an interdisciplinary training (curiosity led) and the aspirations of many students to put in enough effort to pass and obtain a qualification for a job (Biggs and Tang 2011). The performance, passion, and experience of the lecturer is undoubtedly essential to the success by which resilience concepts and ideas are conveyed and understood. The class sizes are also important. At the graduate level 18 students received close one-to-one discussion with the class lecturer, while the undergraduate class of between 40-60 students were often frustrated about the lack of one-to-one engagement of the lecturer. Weekly workshops were implemented subsequently to facilitate the student engagement at undergraduate level. These workshops focused around case study problem solving. This was complemented with weekly student group blogging through the internal university teaching platform Blackboard Learn. The aim was to garner student engagement, boost motivation and to give ownership to the student learning experience. The ways that the blog was used was to have students work in small groups to post summary responses to questions/content covered in the resilience workshops and to build a compendium of collective reflections on key issues in social ecological resilience concepts and practice.

\section{DISCUSSION}

\section{Reflection on challenges}

Our own experiences echo the challenges outlined in the literature, and highlight some additional complexities. The interdisciplinary nature of social-ecological resilience means that students interested in the topic come from diverse disciplinary and cultural backgrounds. The diverse domains of knowledge related to socialecological resilience are thus reflected in the backgrounds of students, making it difficult to create a mutual understanding of the topics. As an example, students in the natural sciences are often confused by the multiple "truths" that can be uncovered by social scientists working in different epistemological traditions. At the same time, social science students trained in interpretative analysis and constructivism sometimes contest the knowability of scientific "truths." For instance, an undergraduate student in one course concluded in feedback that "resilience was an ideology," which reflected a marked difference in the ontology, epistemology, and axiology of the lecturer and the student on the issue of social and environmental change. This gap between lecturer and student understandings illustrates that, as Sriskandarajah et al. (2010) concluded, social-ecological resilience can be difficult to translate into effective educational strategies.

Furthermore, as a relatively new field, there are not yet many models of what constitutes robust science in social-ecological resilience, making it challenging for students and others to effectively judge well-designed research. Social-ecological science is qualitatively and quantitatively different from either social or natural science, because it attempts to link the two. Many of the first generation of SES scientists worked for many years as a scientist of a discipline, e.g., an ecologist, political scientist, or economist, before shifting to an integrated approach of the social and biophysical. However, many of the current generation have no such background, with many scholars going through 
interdisciplinary programs. In the extreme, some feel that their science is "undisciplinary" in that it is stand-alone and distinct from past differentiations. As a result, new approaches need to be held to a different but equally rigorous set of standards for what constitutes good social-ecological science. These and other differences can make the validation of social and ecological drivers highly contested.

Another challenge is that there has been to this point little integration of the literature at the frontier of social-ecological research and education, and more traditional methods textbooks. Nor has there been much integration of social and ecological methods texts, which arguably results from an underappreciation of the common issues and goals (generalizability, causal inference) shared by them. If one were to further develop the methods of social-ecological research, attempting to integrate social and ecological research methods would seem like one fruitful place to start.

\section{Reflection on using case studies as a way to teach social- ecological resilience}

Our own approaches and the pedagogy literature suggest case studies as a useful approach for teaching social-ecological resilience, and here we reflect further on this approach. Case study research is an important tool in the social sciences. It has been malaligned as well as being too specific to support hypothesis testing and thus generalize findings to the broader scientific community (Yin 1984). At the same time, however, case study research has long been regarded as an important method used to understand governance (George and McKeown 1985, Jensen and Rodgers 2001) as it contextualizes barriers and bridges to the success of institutions. Thus case studies can be used to develop a description of the event of interest, to design a more accurate hypothesis, and to guide analysis. One can test hypotheses using data in case studies by examining within-case variances (e.g., differences in governance outcomes between units of the same community or institution), through a longitudinal study (e.g., examining governance processes within the same socialecological system through time), and across entities in a larger population (e.g., one particular rule across two management agencies), as well as a combination of these approaches (Jensen and Rodgers 2001). By the same token, case studies allow for the combined use of quantitative and qualitative data and analysis techniques at different levels of analysis (Netting 1981). This attribute may pair well with student engagement in peer-learning relating to social, ecological, and social-ecological indicators including understanding the basis for assumptions and measurement validity. Finally, case studies can complement statistical studies by focusing on outliers or average cases, and also constitute the grounding for modeling exercises (Bäck and Dumont 2004).

The same reasons that make case study research valuable also makes it a relevant tool for teaching social-ecological resilience: students can understand the depth and context of a case, and examine hypotheses, both individually and collaboratively. By using practical examples to learn new concepts and problem solve, it is easier to gain a common understanding and overcome differences in ontologies. The detailed descriptions provided through case studies can facilitate the identification of ontological controversies and thus open up for such collaborative learning. Also, the analytical versatility of case studies can facilitate dialogue between students from different disciplines and specialized in different methods. Case studies are a useful tool for identifying variables and measurement indicators that best demonstrate theoretical concepts of interest to the student/ researcher. In particular, many of the variables that are of relevance to the "social" in social-ecological resilience, e.g., democracy and power, are considered notoriously difficult to measure because they are often context dependent (George and Bennett 2005). Case studies allow for examination of such contextual factors.

However, there are also limitations and trade-offs in using case studies. A course built on case study analysis may be challenging to evaluate because of the highly contextual nature of the description; it would be difficult to grade a case study assignment as if it were based on a fixed understanding of a phenomena. Case studies also vary in the direct applicability to the desired learning outcomes, in spite of best intentions to minimize differences. Instead, case studies may be as varied as their authors, depending on which variables are highlighted, which time frame bounds the study, and which theoretical lens is framing the analysis. To contribute to higher order learning, the evaluation of a case study should focus on internal consistency as well as the extent to which the case study allows for analysis and theory-testing. Evaluating the extent to which case study learning contributes to a course calls for an evaluation of student engagement, rigor in description as well as analysis, and the extent to which case studies allow students to connect more deeply to their subject matter (Fazey 2010); a rich set of cases under careful scholarship should facilitate discussion, debate, and social learning. Finally, it is important to note that to engage in multidisciplinary problem solving, students may need additional training to be conversant in their classmates' fields.

\section{Opportunities for moving forward}

The literature and our own experiences highlight the many pedagogical opportunities in the important yet challenging task of teaching complex environmental issues and social-ecological resilience in higher education. The consensus from our experiences and the literature is that lectures are not sufficient to fully engage students in these issues. Instead, multiple pedagogical advances can be incorporated into courses, including experiential learning (Krasny et al. 2009), transformative social learning (Sriskandarajah et al. 2010), games (Dieleman and Huisingh 2006), and problem-based learning (Krasny and Roth 2010).

In all of our courses, we found that problem-based and projectbased, e.g., through case studies, learning offers much promise. In some of our own courses, further work is required to build problem-based learning in ways that facilitate learning about the concepts, their application, and how these map onto the socialecological systems and resilience frameworks in a more experiential manner. In the future, it will be important to introduce ways to successfully engage those students who are operating below the cognitive level needed. This could include a combination of problem-based learning and buzz group discussions around a focused set of questions. The key will be to continue to engage the majority of students with social-ecological resilience in ways that are seamless and easy to grasp. Technology, visual representation, and engagement through games and case studies, as well as getting out of the classroom may be the key to this success. 
Problem-based and project-based learning also provided the best opportunity for students to contribute to social-ecological resilience research. Research on case studies with a socialecological lens is tangible, provided a useful learning tool, and in one course (Appendix 2) has resulted in four peer-reviewed submissions to date: an investigation of carbon emissions as a common pool resource issue (K. Lacroix and G. Richards, unpublishedmanuscript), investigating comanagement in two large regions, Gwaii Haanas in British Columbia (S. Gose, A. Paul, A. Firth, and N. C. Ban, unpublished manuscript) and the Inuvialuit Settlement Region in northern Canada (W. Tyson, unpublished manuscript), and a review of Rockfish Conservation Areas 10 years after their implementation in British Columbia (D. Lancaster, D. Haggarty, and N. C. Ban, unpublished manuscript). These papers all highlight possible management changes to improve the environmental issues discussed, and thereby not only provide new social-ecological case studies but also offer solutions.

Teaching can also advance social-ecological research by promoting spaces of collaborative and interdisciplinary thinking. Such spaces are difficult to promote among established scholars because of practical and career path dependencies (Campbell 2005). Teaching interdisciplinary groups of students offers an opportunity to treat students as colleagues and learn from their less path-dependent views. Similarly, project-based, experiential teaching serves not only the purpose of training students but also that of scientific production, which seems particularly important for nascent research fields such as social-ecological systems.

Given that social-ecological resilience is an emerging field, there is a need for development and sharing of teaching materials. One resource that could greatly facilitate the further development of social-ecological education is an online hub that can be used to share experiences in teaching and research, the way that we have done here. This could build on several already existing projects and web sites, including the National Center for Case Study Teaching in Science (http://sciencecases.lib.buffalo.edu/cs/), or the Curriculum for the Bioregion Initiative hosted by the Science Education Resource Center (http://serc.carleton.edu/bioregion/ index.html). The former focuses on specific case study analyses across a range of substantive areas and disciplines, whereas the latter contains a range of pedagogical materials, each oriented around the theme of sustainability.

Several specific functions that such a hub could have that would aid our teaching efforts include the following:

1. A source of methods-oriented material for students learning about social-ecological research, and a basis for students to learn how to conduct social-ecological case studies.

2. A repository for course descriptions and syllabi. Each course can essentially be considered as a case study and examined as such in a consistent way.

3. A forum where specific themes and issues can be discussed by web site members.

We are excited about the prospect of continuing to improve our efforts to teach social-ecological resilience, and to create a community of teachers facing similar challenges and opportunities. In particular, given the diversity of disciplines involved and the interdisciplinary nature of social-ecological systems, an opportunity going forward is to incorporate each other's expertise in our courses through guest appearances. Technology can be particularly helpful in this regard, allowing us to connect students with experts through video-conferencing. Furthermore, given the environmental challenges humanity is facing, inspiring future leaders to think about coupled humanenvironment systems is critical. Indeed, the suggestion has been made that environmental education has the potential to contribute to a resilient world because it may foster attributes of resilient social-ecological systems (Krasny 2009, Krasny et al. 2010, Tidball and Krasny 2011).

Responses to this article can be read online at: http://www.ecologyandsociety.org/issues/responses. $\mathrm{php} / 7517$

\section{Acknowledgments:}

NCB thanks funding support by SSHRC and NSERC, and the Resilience Alliance and Resilience Alliance Young Scholars for providing inspiration in teaching and writing this paper. SVT thanks funding support from the Division of Resource Economics (Humboldt University). MLS would like to thank ASU's School of Sustainability for pedagogical support and the Center for the Study of Institutional Diversity for research support. We thank Mike Petriello for insightful input, and two anonymous reviewers for their constructive feedback.

\section{LITERATURE CITED}

Adger, W. N. 2000. Social and ecological resilience: are they related? Progress in Human Geography 24:347-364. http://dx.doi. org/10.1191/030913200701540465

Adger, W. N. 2006. Vulnerability. Global Environmental Change 16:268-281. http://dx.doi.org/10.1016/j.gloenvcha.2006.02.006

Agrawal, A. 2001. Common property institutions and sustainable governance of resources. World Development 29:1649-1672. http://dx.doi.org/10.1016/S0305-750X(01)00063-8

Bäck, H., and P. Dumont. 2004. A combination of methods: the way forward in coalition research. American Political Science Association, Chicago, Illinois, USA.

Berkes, F., J. Colding, and C. Folke, editors. 2003. Navigating social-ecological systems: building resilience for complexity and change. Cambridge University Press, Cambridge, UK. http://dx. doi.org/10.1017/CBO9780511541957

Bernard, H. R. 2011. Research methods in anthropology: qualitative and quantitative approaches. Alta Mira, Lanham, Maryland, USA.

Biggs, J., and C. Tang. 2011. Teaching for quality learning at university. Fourth edition. Open University Press, McGraw-Hill, Berkshire, UK.

Brundiers, K., and A. Wiek. 2013. Do we teach what we preach? An international comparison of problem- and project-based learning courses in sustainability. Sustainability 5:1725-1746. http://dx.doi.org/10.3390/su5041725 
Burgan, M. 2006. In defense of lecturing. Change: The Magazine of Higher Learning 38:30-34. http://dx.doi.org/10.3200/ CHNG.38.6.30-34

Campbell, L. M. 2005. Overcoming obstacles to interdisciplinary research. Conservation Biology 19:574-577. http://dx.doi. org/10.1111/j.1523-1739.2005.00058.x

Chapin III, F. S., S. R. Carpenter, G. P. Kofinas, C. Folke, N. Abel, W. C. Clark, P. Olsson, D. M. Stafford Smith, B. Walker, O. R. Young, F. Berkes, R. Biggs, J. M. Grove, R. L. Naylor, E. Pinkerton, W. Steffen, and F. J. Swanson. 2010. Ecosystem stewardship: sustainability strategies for a rapidly changing planet. Trends in Ecology \& Evolution 25:241-249. http://dx.doi. org/10.1016/j.tree.2009.10.008

Clark, W. C., and N. M. Dickson. 2003. Sustainability science: the emerging research program. Proceedings of the National Academy of Sciences of the United States of America 100:8059-8061. http://dx.doi.org/10.1073/pnas.1231333100

Cox, M. 2014. Understanding large social-ecological systems: introducing the SESMAD project. International Journal of the Commons 8:265-276.

De Suarez, J. M., P. Suarez, C. Bachofen, N. Fortugno, J. Goentzel, P. Gonçalves, N. Grist, C. Macklin, K. Pfeifer, S. Schweizer, M. Van Aalst, and H. Virji. 2012. Games for a new climate: experiencing the complexity of future risks. Pardee Center Task Force Report. The Frederick S. Pardee Centre for the Study of the Longer-Range FutureBoston University, Boston, Massachusetts, USA.

Dieleman, H., and D. Huisingh. 2006. Games by which to learn and teach about sustainable development: exploring the relevance of games and experiential learning for sustainability. Journal of Cleaner Production 14:837-847. http://dx.doi.org/10.1016/j. jclepro.2005.11.031

Epstein, G., M. Nenadovic, and A. Boustany. 2014a. Into the deep blue sea: commons theory and international governance of Atlantic bluefin tuna. International Journal of the Commons 8:277-303.

Epstein, G., I. Pérez, M. Schoon, and C. L. Meek. $2014 b$. Governing the invisible commons: ozone regulation and the Montreal Protocol. International Journal of the Commons 8:337-360.

Evans, L. S., N. C. Ban, M. Schoon, and M. Nenadovic. 2014. Keeping the 'Great' in the Great Barrier Reef: large-scale governance of the Great Barrier Reef Marine Park. International Journal of the Commons 8:396-427.

Fazey, I. 2010. Resilience and higher order thinking. Ecology and Society 15(3): 9. [online] URL: http://www.ecologyandsociety. org/vol15/iss3/art9/

Fleischman, F. D., N. C. Ban, L. S. Evans, G. Epstein, G. GarciaLopez, and S. Villamayor-Tomas. 2014a. Governing large-scale social-ecological systems: lessons from five cases. International Journal of the Commons 8:428-456.

Fleischman, F. D., B. Loken, G. A. Garcia-Lopez, and S. Villamayor-Tomas. 2014b. Evaluating the utility of common-pool resource theory for understanding forest governance and outcomes in Indonesia between 1965 and 2012. International Journal of the Commons 8:304-336.

Folke, C., T. Hahn, P. Olsson, and J. Norberg. 2005. Adaptive governance of social-ecological systems. Annual Review of Environment and Resources 30:441-473. http://dx.doi.org/10.1146/ annurev.energy.30.050504.144511

Freeman, S., S. L. Eddy, M. Mcdonough, M. K. Smith, N. Okoroafor, H. Jordt, and M. P. Wenderoth. 2014. Active learning increases student performance in science, engineering, and mathematics. Proceedings of the National Academy of Sciences 111:8410-8415. http://dx.doi.org/10.1073/pnas.1319030111

Gallopín, G. C. 2006. Linkages between vulnerability, resilience, and adaptive capacity. Global Environmental Change 16:293-303. http://dx.doi.org/10.1016/j.gloenvcha.2006.02.004

George, A. L., and A. Bennett 2005. Case studies and theory development in the social sciences. Cambridge, MA, MIT Press.

George, A. L., and T. J. McKeown. 1985. Case studies and theories of organizational decision making. Advances in Information Processing in Organizations 2:21-58.

Gunderson, L. H., and C. S. Holling 2002. Panarchy: understanding transformations in human and natural systems. Island Press, Washington, D.C., USA.

Handelsman, J., D. Ebert-May, R. Beichner, P. Bruns, A. Chang, R. Dehaan, J. Gentile, S. Lauffer, J. Stewart, S. M. Tilghman, and W. B. Wood. 2004. Scientific teaching. Science 304:521-522. http:// dx.doi.org/10.1126/science.1096022

Hmelo-Silver, C. E., R. Jordan, L. Liu, and E. Chernobilsky. 2011. Representational tools for understanding complex computersupported collaborative learning environments. Pages 83-106 in S. Puntambekar, G. Erkens, and C. Hmelo-Silver, editors. Analyzing interactions in CSCL. Springer, New York, New York, USA. http://dx.doi.org/10.1007/978-1-4419-7710-6 4

Jacobson, M. J., M. Kapur, H.-J. So, and J. Lee. 2011. The ontologies of complexity and learning about complex systems. Instructional Science 39:763-783. http://dx.doi.org/10.1007/ s11251-010-9147-0

Jensen, J. L., and R. Rodgers. 2001. Cumulating the intellectual gold of case study research. Public Administration Review 61:235-246. http://dx.doi.org/10.1111/0033-3352.00025

King, G., R. O. Keohane, and S. Verba 1994. Designing social inquiry: scientific inference in qualitative research. Princeton University Press, Princeton, New Jersey, USA.

Krasny, M. E. 2009. A response to Scott's concerns about the relevance of environmental education research: applying socialecological systems thinking and consilience to defining research goals. Environmental Education Research 15:189-198. http://dx. doi.org/10.1080/13504620902770352

Krasny, M. E., C. Lundholm, and R. Plummer. 2010. Environmental education, resilience, and learning: reflection and moving forward. Environmental Education Research 16:665-672. http://dx.doi.org/10.1080/13504622.2010.505445

Krasny, M. E., and W. M. Roth. 2010. Environmental education for social-ecological system resilience: a perspective from activity 
theory. Environmental Education Research 16:545-558. http://dx. doi.org/10.1080/13504622.2010.505431

Krasny, M. E., K. G. Tidball, and N. Sriskandarajah. 2009. Education and resilience: social and situated learning among university and secondary students. Ecology and Society 14(2): 38. [online] URL: http://www.ecologyandsociety.org/vol14/iss $2 /$ $\underline{\operatorname{art38/}}$

Laurillard, D. 2002. Rethinking university teaching: a conversational framework for the effective use of learning technologies. RoutledgeFalmer, New York, New York, USA.

Maynard, J. A., P. A. Marshall, J. E. Johnson, and S. Harman. 2010. Building resilience into practical conservation: identifying local management responses to global climate change in the southern Great Barrier Reef. Coral Reefs 29:381-391. http://dx. doi.org/10.1007/s00338-010-0603-8

Mezirow, J. 1991. Transformative dimensions of adult learning. Jossey-Bass, San Francisco, California, USA.

Netting, R. M. 1981. Balancing on an Alp: ecological change and continuity in a Swiss mountain community. Cambridge University Press, Cambridge, UK.

Neubauer, P., O. P. Jensen, J. A. Hutchings, and J. K. Baum. 2013. Resilience and recovery of overexploited marine populations. Science 340:347-349. http://dx.doi.org/10.1126/science.1230441

Ostrom, E. 2009. A general framework for analyzing sustainability of social-ecological systems. Science 325:419-422. http://dx.doi.org/10.1126/science.1172133

Poteete, A. R., M. A. Janssen, and E. Ostrom 2010. Working together: collective action, the commons, and multiple methods in practice. Princeton University Press, Princeton, New Jersey, USA. http://dx.doi.org/10.1515/9781400835157

Ruiz-Primo, M. A., D. Briggs, H. Iverson, R. Talbot, and L. A. Shepard. 2011. Impact of undergraduate science course innovations on learning. Science 331:1269-1270. http://dx.doi. org/10.1126/science.1198976

Shadish, W. R., T. D. Cook, and D. T. Campbell 2002. Experimental and quasi-experimental designs for generalized causal inference. Houghton-Mifflin, Boston, Massachusetts, USA.

Slavich, G. M., and P. G. Zimbardo. 2012. Transformational teaching: theoretical underpinnings, basic principles, and core methods. Educational Psychology Review 24:569-608. http://dx. doi.org/10.1007/s10648-012-9199-6

Springer, L., M. E. Stanne, and S. S. Donovan. 1999. Effects of small-group learning on undergraduates in science, mathematics, engineering, and technology: a meta-analysis. Review of Educational Research 69:21-51. http://dx.doi.org/10.3102/00346$\underline{543069001021}$

Sriskandarajah, N., R. Bawden, C. Blackmore, K. G. Tidball, and A. E. J. Wals. 2010. Resilience in learning systems: case studies in university education. Environmental Education Research 16:559-573. http://dx.doi.org/10.1080/13504622.2010.505434
Tidball, K. G., and M. E. Krasny. 2011. Toward an ecology of environmental education and learning. Ecosphere 2:art21. http:// dx.doi.org/10.1890/ES10-00153.1

Villamayor-Tomas, S., F. D. Fleischman, I. P. Ibarra, A. Thiel, and F. V. Laerhoven. 2014. From Sandoz to salmon: conceptualizing resource and institutional dynamics in the Rhine watershed through the SES framework. International Journal of the Commons 8:361-395.

Yin, R. K. 1984. Case study research: design and methods. Fourth edition. Sage, Thousand Oaks, California, USA. 
Appendix 1. Peer-reviewed papers investigating educational approaches to teaching socialecological resilience to university students.

Brundiers, K., and A. Wiek. 2013. Do we teach what we preach? An international comparison of problem-and project-based learning courses in sustainability. Sustainability 5:1725-1746.

Dieleman, H., and D. Huisingh. 2006. Games by which to learn and teach about sustainable development: exploring the relevance of games and experiential learning for sustainability. Journal of Cleaner Production 14:837-847.

Fazey, I. R. A. 2010. Resilience and higher order thinking. Ecology and Society.

Hmelo-Silver, C., R. Jordan, L. Liu, and E. Chernobilsky 2011. Representational Tools for Understanding Complex Computer-Supported Collaborative Learning Environments. 83106 in: Puntambekar, S., Erkens, G. \& Hmelo-Silver, C. (eds.) Analyzing Interactions in CSCL. Springer US.

Jacobson, M., M. Kapur, H.-J. So, and J. Lee. 2011. The ontologies of complexity and learning about complex systems. Instructional Science 39:763-783.

Krasny, M. E. 2009. A response to Scott's concerns about the relevance of environmental education research: applying social-ecological systems thinking and consilience to defining research goals. Environmental Education Research 15:189-198.

Krasny, M. E., C. Lundholm, and R. Plummer. 2010. Environmental education, resilience, and learning: reflection and moving forward. Environmental Education Research 16:665-672.

Krasny, M. E., and W. M. Roth. 2010. Environmental education for social-ecological system resilience: a perspective from activity theory. Environmental Education Research 16:545558.

Krasny, M. E., K. G. Tidball, and N. Sriskandarajah. 2009. Education and resilience: Social and situated learning among university and secondary students. Ecology and Society 14:38.

Slavich, G. M., and P. G. Zimbardo. 2012. Transformational Teaching: Theoretical Underpinnings, Basic Principles, and Core Methods. Educational Psychology Review 24:569-608.

Springer, L., M. E. Stanne, and S. S. Donovan. 1999. Effects of Small-Group Learning on Undergraduates in Science, Mathematics, Engineering, and Technology: A MetaAnalysis. Review of Educational Research 69:21-51.

Sriskandarajah, N., R. Bawden, C. Blackmore, K. G. Tidball, and A. E. J. Wals. 2010. Resilience in learning systems: case studies in university education. Environmental Education Research 16:559-573.

Tidball, K. G., and M. E. Krasny. 2011. Toward an ecology of environmental education and learning. Ecosphere 2:art21. 
Appendix 2: ENVIRONMENTAL STUDIES 481

Analyzing environmental issues using a social-ecological systems perspective

\author{
University of Victoria, Canada \\ Instructor: Natalie Ban \\ Room: $\quad$ Clearihue Building C115 \\ Time: $\quad$ 16:30-19:20 Wednesdays
}

Office Hours: Thursdays 3-4pm, David Turpin Building B250, or by appointment

Readings: No textbook - all readings are articles accessible through the library

\title{
Course background and description
}

Environmental problems are multi-faceted issues, involving complex interactions between people and the environment. Analyzing environmental issues to formulate options for solutions thus requires interdisciplinary approaches. The concept of social-ecological systems is one such approach that is gaining recognition internationally. This class uses a social-ecological systems lens to better understand, analyze, and find solutions to environmental issues.

Through the assignments in this class, you will learn about and contribute to ongoing research on social-ecological systems. You will work in groups to carry out in-depth case study research. Each group will focus on one case study to understand the resources, actors, and governance system in the case, and how these interact with one another. Case studies in this class will focus on large social-ecological systems, with an emphasis on protected areas. If your case study research is of high calibre, your case study write-up might be used to assist with entering that case into an international comparative database that seeks to analyze conditions leading to successful resource management in large-scale social-ecological systems.

This course is cross-listed with ES 581. The cap for class size (ES 481 and 581 combined) is 30 students.

\section{Learning objectives}

By the end of the course, you should be able to:

- Describe the ideas and theories behind the social-ecological systems framework.

- Assess and analyze a case study using this framework.

- Write a high-quality research essay to describe the findings of your case study research.

- Collaborate effectively with peers on a research project.

\section{Course structure and format ${ }^{1}$}

This class will be a team effort. The format will be a mix of discussions, reading, in-class exercises, and some lectures. This class will place a lot of emphasis in-class participation, and on developing case studies as a way for you to understand and apply the concepts covered in class. To participate effectively in class activities and discussions, you need to read the assigned papers before each class.

\footnotetext{
${ }^{1}$ Minor adjustments to the schedule might be necessary, but due dates for assignments will not change.
} 
Date

Sep. 42013

Sep. 112013

Topic

Introduction to course and overview of social-

ecological systems (SESs)

SES background continued. Overview of the

Social-Ecological Meta-Analysis Database

(SESMAD) project; literature review research skills

Sep. 182013

Case studies as a method; discussion about group project for class; group work

Sep. 252013 SESs: resources, actors; documenting research gaps

Oct. $22013 \quad$ SESs: governance systems; referencing skills

Oct. 92013 SESs: Context and external influences; academic writing skills

Oct. 162013 SESs: Interactions leading to outcomes

Course project, individual assignment 1 due

Oct. 232013 Analyzing interactions-outcomes; presentation skills

Oct. 302013

Analyzing interactions-outcomes continued; academic writing exercise

Nov. 62013

Case study discussions, comparisons of cases

Course project, individual assignment 2 due

Nov 132013 Reading break

Nov. 202013 Class time for working on group report (Dr. Ban away)

Nov. 272013

Dec. 42013

Potential improvements/solutions in cases

Class discussion about case studies, and case

study methodologies; course evaluation

Presentations on case studies

Group report due

* In addition to the assigned readings, you will be expected to find and read relevant materials for your case study (see term paper assignment).

\section{Reading list}

* When you are off-campus, you have to log in to UVic in order to get access to UVic's library subscriptions. Instructions can be found on this UVic website:

http://library.uvic.ca/help/proxy_help/access.html

Agrawal, A. 2001. Common Property Institutions and Sustainable Governance of Resources. World Development 29:1649-1672. (http://www.sciencedirect.com/science/article/pii/S0305750X01000638)

Agrawal, A., and A. Chhatre. 2006. Explaining success on the commons: Community forest governance in the Indian Himalaya. World Development 34:149-166. (http://www.sciencedirect.com/science/article/pii/S0305750X05001889) 
Berkes, F. 2006. From community-based resource management to complex systems: the scale issue and marine commons. Ecology and Society 11(1):45[online]. (http://www.ecologyandsociety.org/vol11/iss1/art45/ES-2005-1431.pdf)

Bruner, A. G., R. E. Gullison, R. E. Rice, and G. A. B. da Fonseca. 2001. Effectiveness of Parks in Protecting Tropical Biodiversity. Science 291:125-128. (http://www.sciencemag.org/content/291/5501/125.short)

Chapin III, F. S., S. R. Carpenter, G. P. Kofinas, C. Folke, N. Abel, W. C. Clark, P. Olsson, D. M. S. Smith, B. Walker, O. R. Young, F. Berkes, R. Biggs, J. M. Grove, R. L. Naylor, E. Pinkerton, W. Steffen, and F. J. Swanson. 2010. Ecosystem stewardship: sustainability strategies for a rapidly changing planet. Trends in Ecology \& Evolution 25:241-249. (http://www.sciencedirect.com/science/article/pii/S0169534709003255)

Cinner, J. E., T. R. McClanahan, M. A. MacNeil, N. A. J. Graham, T. M. Daw, A. Mukminin, D. A. Feary, A. L. Rabearisoa, A. Wamukota, N. Jiddawi, S. J. Campbell, A. H. Baird, F. A. Januchowski-Hartley, S. Hamed, R. Lahari, T. Morove, and J. Kuange. 2012. Comanagement of coral reef social-ecological systems. Proceedings of the National Academy of Sciences 109:5219-5222. (http://www.pnas.org/content/109/14/5219.short)

Collette, B. B., K. E. Carpenter, B. A. Polidoro, M. J. Juan-Jordá, A. Boustany, D. J. Die, C. Elfes, W. Fox, J. Graves, L. R. Harrison, R. McManus, C. V. Minte-Vera, R. Nelson, V. Restrepo, J. Schratwieser, C.-L. Sun, A. Amorim, M. Brick Peres, C. Canales, G. Cardenas, S.-K. Chang, W.-C. Chiang, N. de Oliveira Leite, H. Harwell, R. Lessa, F. L. Fredou, H. A. Oxenford, R. Serra, K.-T. Shao, R. Sumaila, S.-P. Wang, R. Watson, and E. Yáñez. 2011. High Value and Long Life-Double Jeopardy for Tunas and Billfishes. Science 333:291-292. (http://140.109.29.102/pdf/896.pdf)

Cox, M. 2013 in preparation. The SESMAD project. (Will be saved on Moodle.)

Cox, M., G. Arnold, and S. V. Tomás. 2010. A review of design principles for community-based natural resource management. Ecology and Society 15:38. (http://www.ecologyandsociety.org/vol15/iss4/art38/main.html)

De'ath, G., K. E. Fabricius, H. Sweatman, and M. Puotinen. 2012. The 27-year decline of coral cover on the Great Barrier Reef and its causes. Proceedings of the National Academy of Sciences 109:17995-17999. (http://www.pnas.org/content/109/44/17995.short)

Fleischman, Forrest D., Natalie C. Ban, Louisa S. Evans, Graham Epstein, Gustavo GarciaLopez, Sergio Villamayor-Tomas. Governing large-scale social-ecological systems: Lessons from a comparison of five cases. In review in International Journal of the Commons. (Will be saved on Moodle.)

Flyvbjerg, B. 2006. Five Misunderstandings About Case-Study Research. Qualitative Inquiry 12:219-245. (http://qix.sagepub.com/content/12/2/219.short)

Folke, C., T. Hahn, P. Olsson, and J. Norberg. 2005. Adaptive governance of social-ecological systems. Annual Review of Environment and Resources 30:441-473. (http://www.annualreviews.org/doi/abs/10.1146/annurev.energy.30.050504.144511)

Gutierrez, N. L., R. Hilborn, and O. Defeo. 2011. Leadership, social capital and incentives promote successful fisheries. Nature 470:386-389. (http://www.nature.com/nature/journal/v470/n7334/abs/nature09689.html)

Hardin, G. 1968. The tragedy of the commons. Science 162:1243-1248. (http://www.sciencemag.org/content/162/3859/1243.full) 
Olsson, P, Folke, C., Berkes F. 2004. Adaptive comanagement for building resilience in socialecological systems. Environmental Management 34:75-90.

(http://link.springer.com/article/10.1007/s00267-003-0101-7\#page-1)

Ostrom, E. 2009. A general framework for analyzing sustainability of social-ecological systems. Science 325:419-422.

(http://www.sciencemag.org/content/325/5939/419.full?sid=1821e913-6ac4-4634-95f8e5a18ad04712)

Ostrom, E. 2011. Background on the institutional analysis and development framework. Policy Studies Journal 39:7-27. (http://onlinelibrary.wiley.com/doi/10.1111/j.15410072.2010.00394.x/full)

Pollnac, R., P. Christie, J. Cinner, T. Dalton, T. Daw, G. Forrester, N. Graham, and T. McClanahan. 2010. Marine reserves as linked social-ecological systems. Proceedings of the National Academy of Sciences 107:18251-18255. (http://www.pnas.org/content/107/43/18262.short)

Tucker, C. M., J. C. Randolph, and E. J. Castellanos. 2007. Institutions, Biophysical Factors and History: An Integrative Analysis of Private and Common Property Forests in Guatemala and Honduras. Human Ecology 35:259-274. (http://link.springer.com/article/10.1007/s10745-006-9087-0\#)

SESMAD case studies TBD. (will be saved on Moodle)

Young, O. R., E. F. Lambin, F. Alcock, H. Haberl, S. I. Karlsson, W. J. McConnell, T. Myint, C. Pahl-Wostl, C. Polsky, and P. Ramakrishnan. 2006. A portfolio approach to analyzing complex human-environment interactions: institutions and land change. Ecology and Society 11:31 (online). (http://www.ecologyandsociety.org/vol11/iss2/art31/)

\section{Grading and assignments}

Your grade will be based on the following components (see Appendix A for details):

\begin{tabular}{lrll} 
Component & $\begin{array}{l}\text { Percent } \\
\text { of mark }\end{array}$ & \multicolumn{1}{c}{$\begin{array}{l}\text { Due date } \\
\text { Class participation }\end{array}$} \\
Reflections on readings & $\mathbf{2 5 \%}$ & $\begin{array}{l}\text { Reflections due in hard copy } \\
\text { at the beginning of each class }\end{array}$ \\
Leading a discussion on one week's readings & $10 \%$ & $\begin{array}{l}\text { Sign-up in first class } \\
\text { Participation in discussions and activities }\end{array}$ \\
Course project & $\mathbf{7 5 \%}$ & Ongoing \\
Individual assignment \#1 & $25 \%$ & October 16 \\
Individual assignment \#2 & $25 \%$ & November 6 \\
Group report & $20 \%$ & December 4 \\
Presentation & $5 \%$ & December 4
\end{tabular}




\section{Class participation}

Reflections on readings: Your mark for class participation includes weekly reflections. A template will be provided for weekly reflections on readings. $1 \%$ will be deducted for each missed reflection. These are not meant to be onerous, but rather provide a format for you to take notes while doing the readings. The purpose is to encourage everyone to do the readings prior to class so that we can have fruitful in-class discussions. The reflections will be due as hard copies at the beginning of each class. They will not be marked, but they will be reviewed to make sure you made an effort to complete them properly.

Leading a discussion: For each class starting week 2, several students (2-3) will be in charge of leading a class discussion on readings. You will sign up for these during the first class. You can be creative and convey information from the readings in any way you wish (e.g., discussions, debates, role-play, videos, etc). You are encouraged to bring in relevant material in addition to the assigned readings. The first hour of each class will be devoted to these student-led discussions.

Participation in discussions and activities: You are expected to participate actively in class discussions. As part of your class participation, you will also be expected to bring examples from your case study (see course project below) to in-class discussions.

Course project: You will work in groups of four (a group of 3 or 5 may be necessary) to carry out in-depth case study research. Each group will focus on one case study to understand the resources, actors, and governance system in the case, and how these interact with one another. Case studies in this class will focus on large social-ecological systems, with an emphasis on protected areas, and will allow you to apply the concepts covered in class and in the readings. A penalty of $10 \%$ per day applies to late submissions.

The project has three parts: two individual assignments, and a group report.

Individual assignment \#1: Within each group, you will divide key components of social-ecological aspects of your case study. Each person picks one of: governance system, actors, resources, external influences, so that all aspects are covered. Each person will write a well-researched and well-referenced short (700 words maximum; references are extra) paper that summarizes your focal aspect of the case. More detail about this assignment and what content to include will be provided in class. You will receive an individual grade for this assignment.

Individual assignment \#2: Again each group will divide their case study into components, with each person writing a well-researched and well-referenced short (700 words maximum; references are extra) paper that summarizes your focal aspect of the case. The focus here is on interactions and outcomes. More detail about this assignment and what content to include will be provided in class. You will receive an individual grade for this assignment. 
Group report: Your group report serves to coherently synthesize the findings of your case study. This means piecing together the individual components members of your group have already written, editing them to be a coherent piece of writing, and synthesizing the key findings. Your group will be expected to revise and integrate the individual pieces, based on feedback you will have received on these for your previous assignments. More detail will be provided in class about components to include in the group report. You will receive a group grade for this report (i.e., every group member will receive the same mark for this component). Maximum 3000 words, references are extra.

Presentation: During the last day of class, each group will present its case study and findings. The presentation will be in the format of an academic conference presentation. Each group will have 10-15 minutes for the presentation (the time allocation will be finalized based on the total number of groups).

\section{Course policies}

(Excluded here; this lists policies around grading scale, students with disabilities, plagiarism, and academic integrity). 
Appendix 3: ENVS 83

Social-ecological research methods

$\begin{array}{ll}\text { Dartmouth College } & \\ \text { Instructor: } & \text { Michael Cox } \\ \text { Class periods: } & \text { T-Th 10:00-11:50 } \\ \text { Class location: } & \text { Reed 107 } \\ \text { Office location: } & \text { 105 Fairchild } \\ \text { X-hours: } & \text { W 3-3:50 }\end{array}$

\section{Course description and background}

This course is designed to train students in some of the skills that are important in research in human-environment interactions. Such interactions include humans extracting important renewable and non-renewable natural resources such as fish and forests, as well as producing wastes, such as greenhouse gases. This course is particularly recommended for students planning to conduct graduate-level research or senior theses related to human-environment interactions.

The course is oriented around one major activity, which is an individual project in which students will develop research proposals to answer questions regarding some aspect of humanenvironment interactions.

\section{Readings}

We will be using the following textbooks:

Fowler, F.J. 2014. Survey Research Methods, $5^{\text {th }}$ edition. SAGE Publications.

Yin, R.K. 2009. Case Study Research: Design and Methods, $4^{\text {th }}$ edition. SAGE Publications.

\section{Course policies}

(excluded here)

\section{Expectations, Grading and Assignments}

Your grade will be based on the following components:

\section{Class participation: $15 \%$}

Class participation will be evaluated based on your attendance to class periods and your level of activity within those periods. In a course this size I take this part of student evaluation seriously.

\section{Research proposals $(85 \%)$}

The primary project in the class will consist of a research proposal, which you will essentially be working on throughout the term. This project is broken down into many assignments, listed below. The due date for each assignment is listed below in the schedule. Each assignment is due by $5 \mathrm{pm}$ on the date indicated. Please hand in the assignments by emailing them directly to me. 
Additional information on my expectations for each assignment will be discussed in the days leading up to the due date for that assignment.

$\begin{array}{ll}\text { Research question draft 1 } & (5 \%) \\ \text { Research question draft 2 } & (5 \%) \\ \text { Literature review } & (5 \%) \\ \text { Sampling draft } & (10 \%) \\ \text { Survey draft } & (10 \%) \\ \text { Analysis draft } & (10 \%) \\ \text { Presentations } & (10 \%) \\ \text { Proposal final draft } & (30 \%)\end{array}$

\section{Course Schedule}

\section{March 25: Introduction to the class}

Reading: No reading assignment

\section{Discussion:}

1) The approach of this class

2) Major expectations

3) Basic vocabulary for scientific research

4) Architecture of a research proposal/project

5) Skills that are important for human-environment research

6) Brainstorming possibilities for research projects

\section{March 27: Introduction to multi-method research and discussion of acequias project}

Reading: Young, O. R., et al. 2006. A portfolio approach to analyzing complex humanenvironment interactions: institutions and land change. Ecology and Society 11:31 (online). (http://www.ecologyandsociety.org/vol11/iss2/art31/)

\section{Discussion:}

1) The different types of methods and data available for the analysis of humanenvironment interaction

2) Introduction to causal inference

3) Presentation of acequias research in New Mexico as a demonstration of a multi-method research project

4) Brainstorming possibilities for research projects

\section{April 1: Conducting research}

Reading: Yin, chapter 2

Discussion:

1) The basic steps to conducting "normal" research

2) Elements of a research design 
3) Types of research designs

April 3: Evaluating research

Reading: Research evaluation hand-out

Discussion: Criteria for evaluating research

April 8: Types of data and types of analysis

Reading: Yin, chapters 4 and 5

Discussion:

1) Different sources of evidence for research

2) Triangulation

3) Data storage and organization (review of software)

4) Different types of data analysis (review of software)

April 10: Sampling and survey design

Reading: Fowler chapters 2 and 3

Discussion:

1) More construct validity

2) Goals and methods of sampling

3) Types of sampling strategies

Assignment: Research questions draft 1 due

\section{April 15: Types of surveys}

Reading: Fowler chapter 5

Discussion:

1) Methods/types of surveys

2) Research questions thoughts

April 17: Survey design

Reading: Fowler chapters 6 and 7

Discussion:

1) How to write good survey questions

2) Social network analysis

Assignment: Research questions draft 2 due

\section{April 22: Statistics!}

Reading: No reading assignment

Discussion:

1) Review of foundations of statistical thinking

2) Any additional thoughts on research questions

\section{April 24: Statistics!}

Reading: No reading assignment

Discussion: Demonstration of statistical analysis of survey data in Stata

Assignment: Literature reviews due

\section{April 29: Statistics!}


Reading: No reading assignment

Discussion: In-class statistical exercise on survey data

May 1: Work on sampling drafts and surveys

Reading: No reading assignment

Discussion: Q\&A on sampling drafts and surveys.

Assignment: Sampling draft due

May 6: Research an Buen Hombre fisheries

Reading: No reading assignment

Discussion: Molly Wilson guest lecture on Buen Hombre fishery project

May 8: Guest lecture/discussion

Reading: No reading assignment

Discussion: TBD

Assignment: Survey draft due

May 13: Work on proposed analysis

Reading: No reading assignment

Discussion:

1) Comments on surveys

2) Q\&A on analysis sections

May 15: Work on projects in class and receive feedback

Reading: No reading assignment

Discussion: Discussion of class projects

Assignment: Analysis draft due

May 20: Presentations of final proposals

Reading: No reading assignment

Discussion: Student presentations

May 22: Presentations of final proposals

Reading: No reading assignment

Discussion: Student presentations

May 27: Office hours and wrap-up

Reading: No reading assignment

Discussion: Meet to discuss concerns and issues

PROPOSAL FINAL DRAFT DUE JUNE $3^{\text {rd }}$ AT 5PM 
Appendix 4: SOS 321

Policy and Governance in Sustainable Systems

Tuesdays and Thursdays, 12:00 - 1:15 PM

PSH 153

University of Arizona

Instructor: Michael Schoon

Office Hours, Mondays, 10:00-11:00 AM, Tuesdays 11:00 - 12:00 PM, Wrigley Hall 442

\section{Course Description}

Policy and governance in sustainable systems requires integration of theory and practice, as well as micro-level institutional analysis and macro-level policy analysis. All too often solutions are conceived for micro-level problems with limited attention paid to the macro issues. The purpose of this class is to expose students to US and global sustainability issues and policy prescriptions. Using two lenses, institutional analysis and policy analysis, students will apply a broad understanding of sustainability governance to specific issues in the region. We are partnering with ASU's Sustainable Cities network to provide solutions for municipalities in the Phoenix metro area. Students will conduct policy and institutional analyses for them. This class provides students a unique opportunity to integrate theory and practice in the real world of sustainability policy. Student will work to help find solutions to real world problems. Throughout the semester we will explain what exactly that means.

\section{Course Objectives}

Students learn to utilize theories of governance and public policy on environmental issues and the creation of sustainable policy to understand a local issue. Students conduct policy analysis integrating concepts of governance and sustainability directly with real world sustainability issues. Students understand the history of environmental and sustainability policy, how to analyze policy issues, and how to present academic theory and evidence to a practitioner audience.

There are three broad objectives for this course:

1) To provide students with an understanding of the "big ideas" in the study of humannature interactions and be familiar with a number of issues in the environment;

2) To provide students with an understanding of some of the methods for evaluating and studying governance and policy in sustainable systems; and

3) To provide students with real world application.

To facilitate achieving these three broad objectives, students will have a variety of tasks to secure this knowledge. Ultimately, success in our professional lives comes down to three skills critical thinking, oral persuasion, and written communication. The assignments in this class will work on improving our abilities in each.

\section{Typical Class Format}

Most class sessions are structured around the following format: Announcements, Framing the class session -5 minutes

Discussion Leads - 10 minutes

Lecture -45 minutes 
Think-Pair-Share - 15 minutes ( 2 minutes thinking, 5 minutes with partners, 7 minutes sharing)

Wrap-Up - 5 minutes

\section{Textbooks}

1) Bickers, Kenneth and John T. Williams. 2001. Public Policy Analysis: A Political Economy Approach. Houghton-Mifflin. Relevant chapters will be available on Blackboard. Referenced as $(\mathrm{B} \& \mathrm{~W})$.

2) Chasek, Pamela S., David L. Downie, and Janet Welsh Brown. 2010. Global Environmental Politics. $5^{\text {th }}$ edition. Westview Press. The ebook (full text on-line) is accessible through ASU libraries. Available in the bookstore and online, i.e. at Amazon. Referenced as (CDB).

\begin{tabular}{|c|c|c|c|}
\hline Class & Date & Topics & $\begin{array}{c}\text { Readings and } \\
\text { Assignments Due }\end{array}$ \\
\hline \multirow{2}{*}{ Week 1} & $1 / 14$ & $\begin{array}{l}\text { Introduction to Environmental Policy } \\
\text { and Sustainability } \\
\text { Key Points: } \\
\text { - What is environmental policy? } \\
\text { - How does this relate to } \\
\text { sustainability? }\end{array}$ & $\begin{array}{l}\text { Kraft Chapter } 1 \\
\text { (See Blackboard for } \\
\text { all readings except } \\
\text { main text book) } \\
\text { Syllabus }\end{array}$ \\
\hline & $1 / 16$ & $\begin{array}{l}\text { Introduction to Public Policy Analysis } \\
\text { Key Points: } \\
\text { - What is the difference between } \\
\text { government and governance? } \\
\text { - What is the ultimate test of public } \\
\text { policy? }\end{array}$ & $\begin{array}{l}\text { Bickers and } \\
\text { Williams }(B \& W), \\
\text { Ch } 1 \& 2\end{array}$ \\
\hline \multirow[t]{2}{*}{ Week 2} & $1 / 21$ & $\begin{array}{l}\text { Democracy and Problems of Collective } \\
\text { Action } \\
\text { Key Points: } \\
\text { - What are some of the problems of } \\
\text { democracy? } \\
\text { - What are examples of collective } \\
\text { action problems in environmental } \\
\text { issues? } \\
\text { - What is the prisoner's dilemma? }\end{array}$ & $\begin{array}{l}\text { B\&W, Ch } 3 \text { and } 4 \\
\text { QUIZ } 1\end{array}$ \\
\hline & $1 / 23$ & $\begin{array}{l}\text { Introduction to Community Research } \\
\text { Projects }\end{array}$ & \\
\hline \multicolumn{4}{|c|}{ DUE: CODE OF CONDUCT/WORKING PLAN - JAN 28 AT NOON } \\
\hline \multirow[t]{2}{*}{ Week 3} & $1 / 28$ & $\begin{array}{l}\text { Government and Collective Action } \\
\text { Key Points: } \\
\text { - When is the government a good } \\
\text { solution to collective action } \\
\text { dilemmas? In the environment? }\end{array}$ & $\begin{array}{l}\text { B\&W Ch. } 5 \\
\text { QUIZ } 2\end{array}$ \\
\hline & $1 / 30$ & Project 1 Overview & Project Reading 1 \\
\hline Week 4 & $2 / 4$ & Markets and Collective Action \& & B\&W Ch. $6 \&$ Ch. 7 \\
\hline
\end{tabular}




\begin{tabular}{|c|c|c|c|}
\hline & & $\begin{array}{l}\text { Limitations of Markets } \\
\text { Key Points: } \\
\text { - What are some examples of } \\
\text { market solutions to environmental } \\
\text { challenges? } \\
\text { - What are environmental examples } \\
\text { of a public good? Of a CPR? }\end{array}$ & QUIZ 3 \\
\hline & $2 / 6$ & Project 2 Overview & Project 2 Reading \\
\hline \multirow[t]{2}{*}{ Week 5} & $2 / 11$ & $\begin{array}{l}\text { Policy Analysis in America } \\
\text { Key Points: } \\
\text { - What are the differences between } \\
\text { top-down and bottom-up } \\
\text { governance? }\end{array}$ & $\begin{array}{l}\text { B\&W Ch. } 8 \\
\text { QUIZ } 4\end{array}$ \\
\hline & $2 / 13$ & Project 3 Overview & Project 3 Reading \\
\hline \multirow[t]{2}{*}{ Week 6} & $2 / 18$ & $\begin{array}{l}\text { State (and local) Policymaking } \\
\text { Key Points: } \\
\text { - How different are the local and } \\
\text { international policy areas? }\end{array}$ & $\begin{array}{l}\text { Doughman (2007) } \\
\text { Jacobs \& Holway } \\
(2004)\end{array}$ \\
\hline & $2 / 20$ & Project 4 Overview & Project 4 Reading \\
\hline \multicolumn{4}{|c|}{ DUE: PROBLEM ANALYSIS - FEBRUARY 25 AT NOON } \\
\hline \multirow{2}{*}{ Week 7} & $2 / 25$ & $\begin{array}{l}\text { Intro to Global Environmental Politics } \\
\text { Key Points: } \\
\text { - What has caused the emergence of } \\
\text { global environmental politics? }\end{array}$ & $\begin{array}{l}\text { Chasek, Downie, } \\
\text { and Brown (CDB) } \\
\text { Ch. } 1 \\
\text { QUIZ } 5\end{array}$ \\
\hline & $2 / 27$ & $\begin{array}{l}\text { Science and Policymaking } \\
\text { Key Points: } \\
\text { - What are some of the challenges } \\
\text { between scientists \& policymakers? }\end{array}$ & $\begin{array}{l}\text { Steel et al. (2004) } \\
\text { Miller (2009) }\end{array}$ \\
\hline \multirow[t]{2}{*}{ Week 8} & $3 / 4$ & $\begin{array}{l}\text { Actors in Global Environmental } \\
\text { Politics } \\
\text { Key Points: } \\
\text { - What are some of the important } \\
\text { points of interaction between } \\
\text { domestic and international actors? }\end{array}$ & $\begin{array}{l}\text { CDB Ch. } 2 \\
\text { QUIZ } 6\end{array}$ \\
\hline & $3 / 6$ & $\begin{array}{l}\text { International Regimes }- \text { Climate } \\
\text { Change } \\
\text { Key Points: What can we expect from an } \\
\text { international climate regime? }\end{array}$ & $\begin{array}{l}\text { CDB Ch. } 4 \text { (pp. } \\
179-200)\end{array}$ \\
\hline Week 9 & $\begin{array}{l}3 / 11 \\
3 / 13\end{array}$ & \multicolumn{2}{|l|}{ SPRING BREAK } \\
\hline Week 10 & $3 / 18$ & $\begin{array}{l}\text { Parks and Peoples - The Great Debate } \\
\text { Key Points: } \\
\text { - What are the consequences of the } \\
\text { parks-peoples conflict? } \\
\text { DEBATE FORMAT }\end{array}$ & $\begin{array}{l}\text { Brockington et al } \\
\text { (2008) \& Kramer et } \\
\text { al (1997) - pro- } \\
\text { biodiversity; } \\
\text { Brechin et al (2003) }\end{array}$ \\
\hline
\end{tabular}




\begin{tabular}{|c|c|c|c|}
\hline & & & - pro-development \\
\hline & $3 / 20$ & $\begin{array}{l}\text { International Regime Species \& } \\
\text { Habitat } \\
\text { Key Points: } \\
\text { - What is the role of sovereignty in } \\
\text { international natural resource } \\
\text { management? }\end{array}$ & $\begin{array}{l}\text { CDB Ch. } 5 \text { (pp. } \\
\text { 203-245) } \\
\text { QUIZ } 7\end{array}$ \\
\hline \multirow[t]{2}{*}{ Week 11} & $3 / 25$ & $\begin{array}{l}\text { Community-based Natural Resources } \\
\text { Management (CBNRM) } \\
\text { Key Points: } \\
\text { - What are some of the key lessons } \\
\text { learned from the CBNRM and } \\
\text { their policy implications? }\end{array}$ & $\begin{array}{l}\text { Berkes (2007); } \\
\text { Blaikie (2006) }\end{array}$ \\
\hline & $3 / 27$ & \multicolumn{2}{|c|}{$\begin{array}{l}\text { Group Presentation to External Panel } \\
\text { Groups will present their research on project solutions to project } \\
\text { stakeholders }\end{array}$} \\
\hline \multirow{2}{*}{ Week 12} & $4 / 1$ & \multicolumn{2}{|c|}{$\begin{array}{l}\text { Group Presentation to External Panel } \\
\text { Groups will present their research on project solutions to project } \\
\text { stakeholders }\end{array}$} \\
\hline & $4 / 3$ & \multicolumn{2}{|c|}{$\begin{array}{l}\text { Group Presentation to External Panel } \\
\text { Groups will present their research on project solutions to project } \\
\text { stakeholders }\end{array}$} \\
\hline \multirow[t]{2}{*}{ Week 13} & $4 / 8$ & $\begin{array}{l}\text { International Regime Formation } \\
\text { Key Points: } \\
\text { - How do we measure the } \\
\text { effectiveness of an international } \\
\text { environmental regime? }\end{array}$ & CBD Ch. 6 \\
\hline & $4 / 10$ & $\begin{array}{l}\text { Adaptive Management } \\
\text { Key Points: } \\
\text { - What is adaptive management, and } \\
\text { how can it be put into practice? }\end{array}$ & $\begin{array}{l}\text { CDB Ch. 6 \& } \\
\text { Lee (1993) } \\
\text { QUIZ 8 }\end{array}$ \\
\hline \multicolumn{4}{|c|}{ DUE: POLICY BRIEF - APRIL 15 AT NOON } \\
\hline \multirow[t]{2}{*}{ Week 14} & $4 / 15$ & $\begin{array}{l}\text { Land-use in Arizona: Policies and } \\
\text { Trends } \\
\text { Key Points: } \\
\quad \text { What can we learn from Arizona's } \\
\quad \text { land-use legacies? } \\
\text { Guest Lecturer: Milan Shrestha }\end{array}$ & $\begin{array}{l}\text { Redman and Kinzig } \\
\text { (2008); } \\
\text { Sheridan (2001) }\end{array}$ \\
\hline & $4 / 17$ & $\begin{array}{l}\text { Environmental Peacemaking } \\
\text { Key Points: } \\
\text { What is environmental peacemaking and } \\
\text { does it exist? }\end{array}$ & $\begin{array}{l}\text { Conca and Dabelko } \\
(2002) \\
\text { QUIZ } 9\end{array}$ \\
\hline Week 15 & $4 / 22$ & $\begin{array}{l}\text { Beyond the Tragedy of Commons: } \\
\text { Management of Commons } \\
\text { Key Points: } \\
\text { - Why is the Tragedy of the }\end{array}$ & $\begin{array}{l}\text { Dietz et al (2002); } \\
\text { Schlager \& Ostrom } \\
\text { (1992) }\end{array}$ \\
\hline
\end{tabular}




\begin{tabular}{|c|c|c|c|}
\hline & & $\begin{array}{l}\text { Commons so popular? } \\
\text { - Why is it not wholly accurate? }\end{array}$ & \\
\hline & $4 / 24$ & $\begin{array}{l}\text { Population and Development } \\
\text { Key Points: } \\
\text { - How is the concept of sustainability } \\
\text { evolving? }\end{array}$ & $\begin{array}{l}\text { CDB Ch. } 7 \\
\text { QUIZ 10 }\end{array}$ \\
\hline \multirow[t]{2}{*}{ Week 16} & $4 / 29$ & $\begin{array}{l}\text { The Future of Global Environmental } \\
\text { Governance } \\
\text { Key Points: } \\
\text { - What is the relationship between } \\
\text { globalization and the } \\
\text { environment? }\end{array}$ & CDB Ch. 8 \\
\hline & $5 / 1$ & Review Session and Catch-Up & \\
\hline
\end{tabular}

\section{Expectations}

Readings should be done prior to class. The course is designed, so that Tuesdays are primarily focused on theory and Thursdays on real-world practice. You are expected to participate in discussions on both dimensions. This is a unique opportunity to engage directly with real policymakers from both NGOs and state/local government. Remember that you are seen as a representative of the class as a whole, the School of Sustainability, and ASU when you interact with our policymaking partners. You are expected to practice professional and respectful communication and behavior on campus and off. The class project is not an academic exercise. We have been asked for our help. Your recommendations may lead to real policy development in 2014.

\section{The Group Project}

\section{Assignments}

Projects 1-4 are all part of a group project. For those that think of group projects as the bane of their existence, do not despair. The project is structured to alleviate many group problems. Project 1 is designed to "force" the group to come together and mitigate problems in advance. Project 2 is structured to help get various aspects of the project complete. By the time Project 3 comes around, the groups should be functioning well.

This year, we will be engaging in a grand experiment. We will work with GIOS's Sustainable Cities Network to partner with municipalities around the valley on a number of substantive Sustainability topics.

Stakeholders will present an introduction to each of the topical areas early in the semester. After that, we will have group sign ups for the topics. Teams will be selected based on interest on a first come-first serve selection. We will try to match students to the project of their choice. However, the actual teams will be selected by the faculty.

Project \#1- Code of Cooperation -Due Tuesday, January 28 by noon via Blackboard (5 points) Your group is to agree and write a code of cooperation based on class discussions on team building. Your team's code of cooperation should include all actions and items that you have 
all agreed to that will allow your team to successfully work together. Consider how you will arrange to meet, how you will approach the work involved for your project and, importantly, how you will deal with any conflict that arises or with members that are not abiding by the Code of Cooperation to which you have all agreed. This assignment will include splitting up the project into individual tasks, which will become the main work in Project 2 . Should be approximately 1-3 pages double-spaced with 12 point Times New Roman font. This is teamwork. Each team needs to turn in only ONE copy (with one member of your team) on Blackboard.

Project \#2- Problem Analysis and Solution Identification-Due Tuesday, February 25 by noon via Blackboard (15 points)

Students will all work from a problem description developed by their group as a follow-up from Project 1. Each individual will present preliminary findings from their analysis of a section of the group assignment. The specific section of the group project each student will focus on will be defined during Project 1. Frame the problem that needs to be solved and discuss the findings. Students are expected to use academic citations. Should be approximately 1-3 pages doublespaced with 12 point Times New Roman font. See rubrics for guidance about grading criteria. This is an individual assignment. Every student needs to turn in his/her analysis on Blackboard.

Project \#3- Group Presentation - Due March 27 - April 3, in class. Time slot for presentation scheduled in class. (20 points -15 points for the group, 5 based on peer evaluation) Students present their solution and final report as a group. Talks will be 15 minutes long with 5 minutes for Q\&A. For a group of four, two students should present, and two students should lead the Q\&A. See rubrics for guidance about grading criteria. As noted, 5 points of each grade will be based on anonymous peer evaluation of the other members of the group.

Project \#4- Policy Brief -Due Tuesday, April 15 at noon via Blackboard. (15 points) Students are expected to include 5 academic and 5 professional citations. Should be approximately 5-8 pages double-spaced with 12 point Times New Roman font. This is an individual assignment so be sure to start fresh. Do not use text from the prior assignments. You may use sources from prior work. This work will build upon the group projects, particularly the Problem Description and the Presentation. In this paper, individuals will focus on their individual aspects of the group project research. See rubrics for guidance about grading criteria.

\section{Discussion Leads}

Everyone will be assigned a class sessions to serve as a discussion lead. Most classes will have 3 discussion leaders. Discussion leads will have three roles or tasks.

The first task will be to meet with me in the days before your class session, typically at least 2 days beforehand. These meetings will be short, but important. It will benefit you if you can read the readings prior to this meeting.

The second part will require carefully reviewing the readings for your class session. You will then write a 1-page memo on the readings, guided by our meeting and the key questions that I have identified for the class period. The memo should accomplish several things. First, it should provide initial answers to the questions. Second, it should raise any questions or areas that were unclear. Third, it should provide "access" points for a facilitated discussion in class. Feel free to 
discuss any differences or disagreements that you have with the author, weak arguments, etc.

The memos will be due by 4 PM the day before the class that they discuss. If you were to write a memo for the August February 18th class on State Policymaking, for instance, I should have the memo via email by 4 PM on the 17 th.

The third part will take place in class. The Discussion Leads for a given class will lead the class discussion. This should introduce the topic, provide initial answers to the key questions that I raised for the day's readings, and bring forward any other issues. This will cover roughly 10 minutes. Discussion leaders should coordinate before class. You may use PowerPoint or other visualization media, but this is not required. It should draw directly from your memo. This will lead directly into the "think-pair-share" period.

Grading for the leads will be in three tiers: $100 \%, 90 \%$, or $75 \%$ depending on thoroughness, timeliness, and effort.

\section{Rapporteur Memo}

Rapporteurs' tasks are to take notes at meetings of importance. I (hopefully, we) hold our class sessions to be important. In parallel to the Discussion Leads, the Rapporteurs will keep track of discussion in class. In particular, they will note areas of confusion, questions that need further exploration, and important points that were raised. I'm interested in the main points being raised and issues in need of further clarification.

The Rapporteurs will clean up their class notes and submit in memo format before the next class. Again, using the February $18^{\text {th }}$ class as an example, if you acted as Rapporteur for this class, the memo would be due before class on the $20^{\text {th }}$. These will then be posted to our Blackboard site for the class to use in their studying.

Grading will be in two tiers: $100 \%$ or $75 \%$ depending on thoroughness, timeliness, and effort.

\section{Quizzes}

There will be 10 quizzes throughout the semester. Some are take-home and some in-class. You may only makeup quizzes if you notified the instructor of your absence prior to class and received approval for a makeup. Quizzes are worth 1.5 points each.

Final Examination You will have one exam during the semester - a comprehensive final. If something is on the syllabus or is covered in class, you are expected to know it for the exam. Make-ups for exams will only be given by the instructor for illness of the student or death in the student's immediate family; all make-ups will be ORAL exams. If the student does not take the exam on the date scheduled or an approved make-up, they will receive a grade of 0 . Exams may cover materials in the assigned readings, in lectures, in handouts, or in presentations by guest speakers.

Class Participation: Every student starts off with "full points" for this portion of their grade. Excessive absences or not participating in class discussions will lead to loss of points.

Assignments

Code of Conduct/Group Work Plan
Points

5 
Quizzes (10)

Problem Analysis/Prospectus (individual)

Group Presentation

Policy Briefs (individual)

Discussion Lead

Rapporteur Memo

Final Exam

Class Participation
15

15

15

15

10

5

15

5

100

Required Readings - To be found on Blackboard

Berkes, Fikret. (2007). Community-based conservation in a globalized world. Proceedings of the National Academy of Sciences 104 (39):15188-15193

Blaikie, P. (2006). Is Small Really Beautiful? Community-based Natural Resource Management in Malawi and Botswana. World Development 34 (11):1942-1957.

Brechin, Steven R., Peter R. Wilshusen, Crystal L. Fortwangler, \& Patrick C. West (2003). Conservation and Development at the Turn of the Twenty-First Century - Chapter 1. In Contested Nature: Promoting International Biodiversity with Social Justice in the TwentyFirst Century, pp. 1-22, State University of New York Press: Albany.

Brockington, Dan, Rosaleen Duffy, \& Jim Igoe. (2008). The Imperative for Conservation Chapter 3. In Nature Unbound: Conservation, Capitalism, and the Future of Protected Areas, pp. 47-62, Earthscan Press: London.

Conca, K. and G. Dabelko. (2002). Environmental Peacemaking. pp. 1-22, The Johns Hopkins University Press: Baltimore.

Dietz, T. et al. (2002). The Drama of the Commons, Chapter 1. In E. Ostrom, T. Dietz, N. Dolsak, P. Stern, S. Stonich, and E. Weber (eds.), The Drama of the Commons p. 3-35, Washington, DC: The National Academy Press.

Doughman, P.M. (2007). California's Climate Change Policy: Raising the Bar. Environment 49 (7): 34-43.

Jacobs, K. and J. Holway. (2004). Managing for sustainability in an arid climate: Lesson learned from 20 years of groundwater management in Arizona, USA. Hydrogeology Journal 12, 5265.

Kraft, M. (2011). Environmental Problems and Politics. In Environmental Policy and Politics, $5^{\text {th }}$ Ed. Pp. 1-25. Boston: Longman.

Kramer, Randall, Carel van Schaik, \& Julie Johnson. (1997). Minimizing Species Loss: The Imperative of Protection - Chapter 2. In Last Stand: Protected Areas and the Defense of Tropical Biodiversity, pp. 15-35, Oxford University Press: Oxford.

Lee, Kai. (1993). Compass and Gyroscope: Integrating Science and Politics for the Environment. pp. 51-86, Washington, DC: Island Press.

Miller, N. (2009). Uncertain science - uncertain politics. In Environmental Politics: Stakeholders, Interests and Policymaking. 2nd edition, p. 131--148, London: Routledge.

Redman, C. L. \& A. P. Kinzig. (2008). Water can flow uphilll: A narrative of Central Arizona. In Redman, C. L., \& Foster, D. R. (eds.) Agricultural Landscapes in Transition: Comparisons of Long-term Ecological and Cultural Change. Oxford University Press, New York, NY, pp $238-271$ 
Schlager, E. and E. Ostrom. (1992). Property Rights Regimes and Natural Resources: A Conceptual Analysis. Land Economics 68 (3): 249-262.

Sheridan, T. E. (2001). Cows, condos, and the contested commons: The political ecology of ranching on the Arizona-Sonora borderlands. Human Organization, 60(2), 141-152.

Steel, B., P. List, D. Lach, and B. Shindler. (2004). The role of scientists in the environmental policy process: a case study from the American west. Environmental Science \& Policy 7 (1):1-13.

West, P., J. Igoe, and D. Brockington. (2006). Parks and Peoples: The Social Impact of Protected Areas. Annual Review of Anthropology 35 (1):251-277.

\section{Writing}

Students are expected to use the APA style of citation in this class. Please refer to ASU Library's page for advice about this format (http://libguides.asu.edu/content.php?pid=3172\&sid=16506).

Students are encouraged to seek help with the Writing Center, TA, or instructor prior to turning in an assignment. There are no "re-writes" in this course, so ask questions prior to the due date.

Academic Integrity, other policies, marking rubrics

(excluded here) 


\section{Appendix 5:}

The social, economic, and institutional perspectives in the co-management of MPAs

Marie Curie Initial Training Network (Call FP7-PEOPLE-2011-ITN), funded by the European Commission within the 7th Framework Program

\section{University of Murcia, Spain}

Module 1: Community-based management and Socio-Ecological Systems: CPR theory and beyond

Instructor: Sergio Villamayor-Tomas

Location: Department of Economics (TBA)

Hours: $\quad$ Session1: 09/22/2013 (11:00-13:30)

Session2: 09/22/2013 (15:30-17:30)

\section{Mandatory readings}

Basurto, Xavier, and Elinor Ostrom. 2009. Beyond the Tragedy of the Commons. Economia delle Fonti di Energia e dell'Ambiente LII (1):35-60.

Berkes, Fikret. 2005. Commons theory for marine resource management in a complex world. Senri Ethnological Studies 67:13-31.

Evans, Louisa, Ban C. Natalie, Schoon, Michael, Nenadovic Mateja. Keeping the 'Great' in the Great Barrier Reef: Large-scale governance of the Great Barrier Reef Marine Park, (excerpt), under review in the International Journal of the Commons.

\section{Module description}

This Module introduces common pool resource (CPR) theory and recent extensions for the study of socio-ecological systems (SES).

Traditional economic analyses of common pool resources such as forests, irrigation systems and fisheries prescribed the collapse of those resources unless they are managed through private or government-controlled property right systems. As evidence began to question that diagnosis, attention turned to exploring the resource, social and institutional conditions under which groups of users can manage shared resources collectively through common property regimes (i.e., community-based management).

In the last decade CPR theory has evolved to integrate political ecology as well as ecology themes such as the role of political elites and dynamics, resource distribution inequities, socioecological resilience and adaptive management.

The Module consists of two sessions, each of which includes a lecture and a hands-on learning activity (an economic experiment to be played among students and a case study analysis based on content analysis)

\section{Module objectives}

Students will:

- get acquainted with mainstream institutional economics theory of community-based natural resource management (CPR theory) and extensions.

- get familiarity with two of the methods most frequently used by scholars contributing to CPR theory: Economic experiments and content analysis-based meta-analysis. 
- develop a critical understanding of the different institutional options (government control, private property rights and markets, and common property systems) for natural resource management at local levels

\section{Program}

\section{Session 1: concepts and early CPR theory}

1.1 Concepts : community \& management

1.1.1 Community vs. management

1.1.2 Approaches to community-based management: common property/institutional economics, traditional ecological knowledge, political ecology, ecological economics

1.2 Early theory

1.2.1 Three powerful images: prisoner's dilemma/ tragedy of the commons, rent dissipation, free riding behavior

1.2.1.1 In-class experiment: social dilemmas (see appendix 1)

1.2.1.2 Traditional prescriptions: government and private ownership

\section{Session 2: Conventional CPR theory and beyond}

2.1 Common Pool Resource (CPR): tenets and critiques

2.1.1 Conceptual clarifications: common property vs. common pool resources vs. open access vs. collective action problems

2.1.2 Evidence questioning traditional CPR theory: private and government property systems can fail; common property can work.

2.2 Critics to conventional CPR theory: the political and ecological gaps

2.3 Moving forward

2.3.1 The role of power: decentralization, institutional politics, social movements

2.3.2 Ecological thinking: resilience, robustness and adaptability.

2.3.3 Scalability of CPR theory

2.3.3.1 In-class exercise: Mobilizing qualitative evidence to test SES-related theory (see appendix 2).

Module 1: $\quad$ Community-based management and Socio-Ecological Systems: CPR theory and beyond

Session 2: $\quad$ Conventional CPR theory and beyond

\section{In-class activity: Mobilizing qualitative evidence to test SES-related theory}

This activity is based on Evans et al.'s and Basurto and Ostrom (2009), which are mandatory readings for this module.

Thinking about cooperation and sustainable management of natural resources...

Much of the community-based management theory understands sustainability as fundamentally mediated by cooperation processes. As we will discuss in class, cooperation to develop resource management rules and comply with them should not be taken for granted and needs to be explained. As pointed in the introductory articles, an important set of explanations are related to the role of institutions (i.e., rules and norms that constraint individual behavior). Some of those explanations can be translated into management principles (see readings). Although those principles seem pretty obvious, the causal mechanisms behind 
their relevance are not that easy to formulate. Why clear boundaries, participation and environmental and social monitoring contribute to cooperation and thus sustainable management? Which assumptions do we need to make?

\section{Preparing for in class-activity:}

The Great Barrier Reef Marie Park (GBRMP) can be characterized as a relatively successful case of large scale management, particularly after some reforms in 2004. Assessing the "success" of a management system in such a complex context is not easy task though. Boundaries on SES are difficult to draw, and so are the boundaries and interactions between its SES components. Based on Evans et al.'s text and building on the SES framework, please answer the following questions in groups of two:

- Which Governance system (from pieces of regulation to specific measures) can we identify in the GBRMP case?

- How many different types of marine resources are relevant (fishes, corals...)?

o Have they characteristics that may facilitate or hinder management?

- How about actors or groups of them and their characteristics (from resource users like commercial and recreational fishers to officials and public organizations)?

- Can we identify relevant CPR properties contributing to successful governance of the GBRMP?

Please, use the table provided to record quotes from the text ("quotes" column) and assign them codes of governance system, types of resources, actor groups and properties of them ("SES components and properties" column).

\section{References}

\section{Cited in the presentation}

Acheson, James M. 2006. Institutional Failure in Resource Management. Annual Review of Anthropology 35:117-134.

Agrawal, Arun. 1994. I don't need it but you can't have it: Politics on the commons. Pastoral Development Network 36:36-55.

Agrawal, Arun. 2001. Common Property Institutions and Sustainable Governance of Resources. World Development 29 (10):1649-1672.

Agrawal, Arun. 2003. Sustainable Governance of Common Pool Resources: Context, Methods, and Politics. Annual Review of Anthropology 32 (1):243-262.

Agrawal, Arun, and Clark C. Gibson. 1999. Enchantment and Disenchantment: The Role of Community in Natural Resource Conservation. World Development 27 (4):629-649.

Agrawal, Arun, and Elinor Ostrom. 2001. Collective Action, Property Rigths and Decentralization in Resource Use in India and Nepal. Politics and Society 29 (4):485-514.

Basurto, Xavier, and Elinor Ostrom. 2009. Beyond the Tragedy of the Commons. Economia delle Fonti di Energia e dell'Ambiente LII (1):35-60.

Berkes, Fikret. 2004. Rethinking Community-Based Conservation. Conservation Biology 18 (3):621-630.

Berkes, Fikret. 2005. Commons theory for marine resource management in a complex world. Senri Ethnological Studies 67:13-31.

Bodin, Örjan, and Beatrice I. Crona. 2008. Management of Natural Resources at the Community Level: Exploring the Role of Social Capital and Leadership in a Rural Fishing Community. World Development 36 (12):2763-2779. 
Epstein, Graham, Jessica Vogt, Sarah Mincey, Michael Cox, and Burney Fischer. 2013. Missing ecology: integrating ecological perspectives with the social-ecological system framework. International Jounal of the Commons 7 (2).

Nielsen, Jesper Raakjær, Poul Degnbol, K. Kuperan Viswanathan, Mahfuzuddin Ahmed, Mafaniso Hara, and Nik Mustapha Raja Abdullah. 2004. Fisheries co-management-an institutional innovation? Lessons from South East Asia and Southern Africa. Marine Policy 28 (2):151-160.

Olsson, Per, Carl Folke, and Fikret Berkes. 2004. Adaptive Comanagement for Building Resilience in Social-Ecological Systems. Environmental Management 34 (1):75-90.

Ostrom, Elinor. 1998. A Behavioral Approach to the Rational Choice Theory of Collective Action: Presidential Address, American Political Science Association, 1997. The American Political Science Review 92 (1):1-22.

Ostrom, Elinor. 2007. A diagnostic approach for going beyond panaceas. Proceedings of the National Academy of Sciences 104 (39):15181-15187.

Ostrom, Elinor. 2009. A general framework for analyzing sustainability of Social-Ecological Systems. Science 325 (5939):419-422.

Ostrom, Elinor, Roy Gardner, and James Walker. 1994. Rules, Games and Common Pool Resources. Michigan: Michigan University Press.

Ribot, Jesse C., Arun Agrawal, and Anne M. Larson. 2006. Recentralizing While Decentralizing: How National Governments Reappropriate Forest Resources. World Development 34 (11):1864-1886.

Schlager, Edella, William Blomquist, and Shui Yan Tang. 1994. Mobile flows, storage, and selforganized institutions for governing common-pool resources. Land Economics 70 (3):294.

Steins, N. A. , and V. M. Edwards. 1999. Collective action on common pool resource management: the contribution of a social constructivist perspective to existing theory. Society and Natural Resources 12:539:557.

Tang, Shui Yan, and Ching-Ping Tang. 2001. Negotiated Autonomy: Transforming Self-Governing Institutions for Local Common-Pool Resources in Two Tribal Villages in Taiwan. Human Ecology 29 (1):49-67.

\section{Marine resources related references}

Berkes, F. 2005. Commons theory for marine resources management in a complex world. Senri Ecological Studies 67:13-31.

Bodin, Ö. and B. I. Crona. 2008. Management of natural resources at the community level: exploring the role of social capital and leadership in a rural fishing community." World Development 36(12): 2763-2779.

Cinner, J.E. 2007. Designing marine reserves to reflect local socioeconomic conditions: lessons from long-enduring customary management systems. Coral Reefs 26(4): 1035-1045.

Harkes, I. 2006. Fisheries Co-management, The Role of Local Institutions and Decentralization in Southeast Asia: With Specific Reference to Marine Sasi in Central Maluku, Indonesia. PhD Dissertation, Centre of Environmental Sciences (CML), Faculty of Social and Behavioural Sciences, Leiden University.

Leal, D. 1998. Community-run fisheries: avoiding the "tragedy of the commons." Population and the Environment 19(3): 225-245.

Pinto da Silva, P. 2004. "From common property to co-management: lessons from Brazil's first maritime extractive reserve. Marine Policy 28(5):419-428.

Pomeroy, R.S., B.M. Katon, and I. Harkes. 2001. Conditions affecting the success of fisheries comanagement: lessons from Asia. Marine Policy 25: 197-208.

Quinn, C. H., M. Huby, H. Kiwasila, and J. C. Lovett. 2007. Design principles and common pool resource management: An institutional approach to evaluating community management in semi-arid Tanzania. Journal of Environmental Management 84: 100-113.

Pinkerton, E., and M. Weinstein. 1995. Fisheries That Work: Sustainability Through Community-based Management. The David Suzuki Foundation, Vancouver, CA. 
Rout, S.P. 2006. Co-Management of Common Property Resources: A Case Study of Supra-National, National and Sub-National Institutions in Fisheries Management around Chilika Lake in Orissa, India. Presented at The Eleventh Conference of the International Association for the Study of Ruddle, K. 1996. Boundary definition as a basic design principle of traditional fishery management systems in the Pacific Islands. Geographische Zeitschrift 84(2):94-102. Common Property, June 19-23, 2006, Bali, Indonesia.

Steins, N. A. and V. M. Edwards. 1999. Collective action on common pool resource management: the contribution of a social constructivist perspective to existing theory. Society and Natural Resources 12: 539:557.

Weinstein, M. S. 2000. Pieces of the puzzle: solutions for community-based fisheries management from native Canadians, Japanese cooperatives, and common property. Georgetown International Environmental Law Review 12(2):375-412. 


\section{Appendix 6: \\ Resilience for Sustainable Development}

The University of Reading

School of Archaeology, Geography and Environmental Sciences

Department of Geography

Instructor: Emily Boyd

Spring term 2015

The University of Reading

\section{OBJECTIVE}

To provide insights into the theory and practice of resilience for sustainable development

\section{INTRODUCTION}

Development and sustainable development thinking are faced with significant challenges in rethinking their futures amid global environmental change. In particular climate change has major consequences for governance and human livelihoods in developing countries. It poses challenges to the management of extreme events and exacerbates existing problems of water scarcity and degradation of natural resources. This lecture series is concerned with these consequences. Most importantly global environmental change has implications for the lives and livelihoods of millions of people around the globe. Uncertainty surrounds the environmental stresses that interact with human vulnerability, and the knock on effect on extreme poverty.

Against this backdrop we see increasing attention paid to resilient development and to policy strategies that include mitigation and adaptation to climate change. These actions have yet to demonstrate their benefits in tackling the stress and poverty dimensions of global uncertainty. For example, mitigation schemes through the Kyoto Protocol's Clean Development Mechanisms are often criticized for their failures of governance. The design of such schemes only provides benefit to single market actors while marginalizing a multitude of local actors, in particular the poorest. Meanwhile poorer communities reliant on natural resources for their livelihood are often locked into national policies, incentives and processes that continue to exacerbate the degradation of these resources. Similarly, adaptation interventions in response to climate change provide limited insights into how people should manage the interaction between 'surprise' events, such as flooding or cyclones, and human vulnerability. The question is whether there a trade-off between adapting/mitigating climate change and development? Can a reevaluation of development through a resilience lens square this circle?

'Resilience' has come to mean many things to many people and has raised strong opposition by some to the idea that it is possible to identify a desirable point at which societies could agree to stabilize emissions, deforestation or overfishing. In a world that is unpredictable and is marked by vulnerability and risk, people remain poor, marginalized, discriminated against and dependent on powerful elites. Yet, global environmental change offers the opportunity to act as a circuit 
breaker in other words to rethink the way societies manage and govern the natural environment. Perhaps resilience can help scholars and practitioners to understand better how societies can continue to develop under the stress posed by global environmental change? For example, what policy responses and institutional changes are in train in anticipation of the threats of global environmental change? Can resilience help us to reformulate our thinking about the status quo and trigger ideas for transformation to avoid tipping points?

\begin{abstract}
Aims:
The aim of this lecture series is to provide a unique and a systematic evaluation of resilience as both theoretical lens and operational concept, one through which to re-examine how varieties of development theory (e.g. modernism, neoliberalism) deals with global environmental change and uncertainty, with a particular focus on climate change and its consequences. Of particular importance is the effort to advance understanding of social change as part of the relationship between nature and society.

On completion of this module it is expected that students will be able to:

- Appreciate the range of interpretations given to the term resilience

- Understand how resilience is been approached, used and measured

- Critically examine the practical implications arising from a vision of sustainable development in both developed and less developed countries

- Synthesize both existing work and individual thought into a coherent, logically structured and well-written essay
\end{abstract}

\title{
TIMETABLE
}

Teaching will be by $10 \mathrm{x}$ Lecture and $10 \mathrm{x}$ Seminars

\section{LECTURE TOPICS}

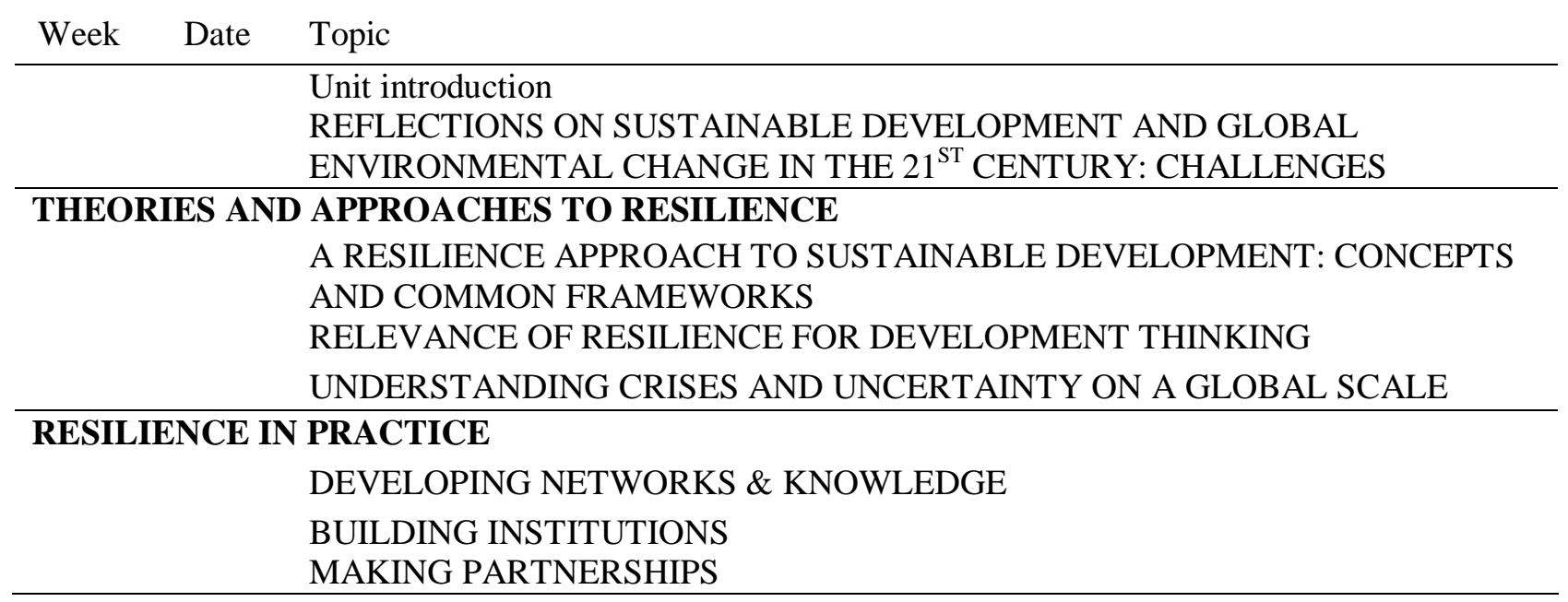


NEW AVENUES, LIMITS AND DEVELOPMENT RECONFIGURATIONS

ADAPTIVE GOVERNANCE, SOCIAL LEARNING AND TRANSFORMATIONS

BARRIERS AND LIMITS TO RESILIENCE FOR SUSTAINABLE DEVELOPMENT

RETHINKING DEVELOPMENT

FINAL GROUP PRESENTATIONS

Lecture slides will be made available on Blackboard along with a list of further reading

\section{ASSESSMENT}

Assessment is a combination of coursework (50\%) and examination (50\%).

The exam will last 2 hours, and you will be required to answer 2 questions from a choice of 5 .

\section{Please note that any of the topics covered in the unit lectures can potentially be included in the exam.}

The coursework will consist of an essay - maximum 2,000 words and a group case study. Please note that although this is an essay, you are encouraged to make good use of tables, graphs, diagrams etc.

You're free to choose one of the following 4 essay questions:

1. What is the definition of resilience and where does it originate?

2. How do the key concepts vulnerability and adaptation relate to resilience?

3. What role do networks play in building resilience? Refer to a case study from the literature.

4. How useful is resilience theory for the practice of environmental management? Use examples from the literature.

\section{Group work case study}

The group work assignment should be presented as poster and should examine a case study to understand 'what works' and what is resilient about a given example. The case should focus on a successful initiative or co-management either in rural or urban context. Can you find an example of a network where the institutions have been particularly successful at creating new opportunities or outcomes that are both 'green' and 'development' focused? Can you find a case of how information and knowledge is channelled to different actors through leaders or networks in ways that makes a difference to the practical outcomes of managing the environment for 
people? Examples could include the co-management of a nature reserve, the management of the green spaces campus at the University of Reading, or it could focus on a network process where municipality and scientists are interlinked in important ways to prepare for early warning. Can you find ways that people are measuring resilience? You will work in groups of 3-5 people. The poster should try to examine one key aspect of the system and should introduce the concept, present the key method of assessment, the findings, analysis (strengths and weaknesses) and conclusions, and illustrate with photographs and images.

\title{
Deadline for all coursework submission
}

13.00 on 27 March, 2015

\begin{abstract}
All work must be handed in to the Geography and Environmental Science Department with a front sheet confirming that it is the work of the student.
\end{abstract}

The front sheet is stamped with the date/time of submission.

\section{INTODUCTORY TEXTS}

As you will soon be aware there is a huge literature on resilience for sustainable development, and in a series of lectures such as this it is really only possible to scratch the surface. This is good news and shows the urgency and vitality of the topic, but can be problematic as important publications are likely to emerge during the teaching of the unit. The following is but a small selection of key introductory texts:

\section{Introductory texts}

Adger, W.N., 2006, Vulnerability, Global Environmental Change, 16, 268-281

Berkes, F \&Folke, C (Eds.), 1998, Linking social and ecological systems: management practices and social mechanisms for building resilience, Cambridge, Cambridge University Press

Boyd, E. and C. Folke (eds), 2012: Adapting Institutions: Governance, Complexity and Social Ecological Resilience. Cambridge: Cambridge University Press.

Folke, C. Resilience. Global Environmental Change, 16.

Folke, C, Carpenter, S, Elmqvist, T, Gunderson, L, Holling C.S. \& Walker, B, 2002, Resilience and Sustainable Development: Building Adaptive Capacity in a World of Transforamtions, AMBIO: A Journal of the Human Environment, 31:5, 437-440 
Handmer, J.W. \& Dovers, S.R., 1996, A Typology of Resilience: Rethinking Institutions for Sustainable Development, Organisation Environment, 9, 482-511

Maler, K, 2008, Sustainable Development and Resilience in Ecosystems, Environmental Resource Economics, 39, 17-24

Perrings, C, 2006, Resilience and Sustainable Development, Environment and Development Economics, 11, 417-427

Walker, B.H. \& Salt, D, 2006, Resilience thinking: sustainable ecosystems and people in a changing world, Washington DC, Island Press

Walker, B, Holling, C.S., Carpenter, S.R. \& Kinzig, A, 2004, Resilience, Adaptability and Transformability in Social-ecological Systems, Ecology and Society, 9:2, 5

\section{Online resources}

The Resilience Alliance - http://www.resalliance.org/

This website has explanations of basic concepts such as resilience, adaptive capacity and panarchy. Also has a range of case studies in urban and marine environments.

Stockholm Resilience Centre - http://www.stockholmresilience.org/

This website focuses on research into the governance of social-ecological systems and has a wide range of publications to read on resilience and other climate change related topics.

Eldis - http://www.eldis.org/go/topics/resource-guides/climate-change/key-issues

This website is part of a family of knowledge services provided by the Institute of Development studies in Sussex. It has information and resources on a wide range of climate change related topics including resilience, adaptive social protection, and community involvement in climate change strategies.

Climate Centre: Partners for Resilience - http://www.climatecentre.org/site/partners-forresilience

This website is based on collaboration between five organisations (The Dutch Red Cross, the Red Cross Climate Centre, CARE Netherlands, Cordaid, and Wetlands International in order to help improve the resilience of vulnerable communities

Gaia Foundation - http://www.gaiafoundation.org/climate-change-resilience

This organisation argues for a holistic approach to climate resilience through the integration of communities and ecosystems.

UNISDR (International Strategy for Disaster Reduction) - Making Cities Resilient http://www.unisdr.org/campaign/resilientcities/

A UN campaign aimed at educating people about urban resilience and encouraging individuals to take action wherever they can. 
IUCN (International Union for the Conservation of Nature) -

http://www.iucn.org/cccr/resilience_to_climate_change/

This website places particular focuses on improving the resilience of coral reef ecosystems.

LifeMosaic - http://www.lifemosaic.net/en/home.php

LifeMosaic is an organisation determined to help indigenous communities become more

knowledgeable and thus resilient to the possible impacts of climate change.

Living with Environmental Change - Adaptation and Resilience to Climate Change http://www.lwec.org.uk/activities/arcc

Living with environmental change is an organisation trying to address a series of environmental challenges, including that of climate change. One of its key activities is the Adaptation and Resilience to Climate Change programme.

Adaptation and Resilience in a Changing Climate - Co-ordinating Network - http://www.arcccn.org.uk/

The Adaptation and Resilience in a Changing Climate Co-ordinating Network brings together a wide range of stakeholders to work on multiple resilience projects, for example with regards to water resource sustainability, urban climates, and resilient transport networks for the future.

Natural England -

http://www.naturalengland.org.uk/ourwork/climateandenergy/climatechange/default.aspx Natural England works with the research community to develop and implement mitigation, vulnerability, adaptation, and drought based projects.

\section{National UK Government Sites}

UK Climate Projections (DEFRA) - http://ukclimateprojections.defra.gov.uk/

Wales 'Building resilience to climate change' -

http://wales.gov.uk/consultations/environmentandcountryside/climatechangeresilience/?lang=en

Foreign \& Commonwealth Office article on building global resilience to climate change http://www.fco.gov.uk/en/news/latest-news/?view=Speech\&id=657334482

The Joint Nature Conservation Committee are key advisors to the government http://jncc.defra.gov.uk/page-3910

Scottish biodiversity and ecosystem resilience -

http://www.scotland.gov.uk/Publications/2009/12/08130729/1

\section{UK Local Government}

London mayoral climate change adaptation strategy - http://www.london.gov.uk/who-runslondon/mayor/publications/environment/london-climate-change-adaptation-strategy

Local governments and climate change - http://www.local.gov.uk/climate-change 
Climate resilience partnership in Yorkshire and Humberside -

http://www.yourclimate.org/pages/about-climate-change-partnership

West Midlands climate adaptation partnership http://www.sustainabilitywestmidlands.org.uk/projects/?/Public+Sector+-

+Climate+adaptation+partnership/1622

Climate Local initiative - http://www.local.gov.uk/web/guest/the-lga-and-climate-change//journal_content/56/10171/3574359/ARTICLE-TEMPLATE

\section{US Government Sites}

The US Environmental Protection Agency's CREAT (Climate Resilience and Awareness Tool) http://water.epa.gov/infrastructure/watersecurity/climate/creat.cfm

NOAA (National Ocean and Atmospheric Administration) Coral Reef Conservation Programme - http://coralreef.noaa.gov/

NOAA Climate Project Office linking climate science with practical challenges in coastal areas http://www.cpo.noaa.gov/cpo_pa/sarp/index.jsp?pg=./cpo_pa/cpo_pa_index.jsp\&pa=sarp\&sub= coast.jsp

\section{Other Sites}

Climate change and parks in Australia -

http://www.environment.gov.au/parks/publications/climate/index.html

Australian Government Department of Agriculture, Fisheries and Forestry http://www.daff.gov.au/climatechange

Government of India Ministry of Environment \& Forests climate change vulnerability and adaptation - http://www.envfor.nic.in/cc/adapt.htm 